\title{
Chemical oxidative potential of secondary organic aerosol (SOA) generated from the photooxidation of biogenic and anthropogenic volatile organic compounds
}

\author{
Wing Y. Tuet ${ }^{1}$, Yunle Chen ${ }^{2}$, Lu Xu ${ }^{1}$, Shierly Fok ${ }^{1}$, Dong Gao ${ }^{3}$, Rodney J. Weber ${ }^{4}$, and Nga L. Ng ${ }^{1,4}$ \\ ${ }^{1}$ School of Chemical and Biomolecular Engineering, Georgia Institute of Technology, Atlanta, GA, USA \\ ${ }^{2}$ School of Materials Science and Engineering, Georgia Institute of Technology, Atlanta, GA, USA \\ ${ }^{3}$ School of Civil and Environmental Engineering, Georgia Institute of Technology, Atlanta, GA, USA \\ ${ }^{4}$ School of Earth and Atmospheric Sciences, Georgia Institute of Technology, Atlanta, GA, USA
}

Correspondence to: Nga L. Ng (ng@chbe.gatech.edu)

Received: 26 September 2016 - Published in Atmos. Chem. Phys. Discuss.: 7 October 2016

Revised: 26 December 2016 - Accepted: 28 December 2016 - Published: 19 January 2017

\begin{abstract}
Particulate matter (PM), of which a significant fraction is comprised of secondary organic aerosols (SOA), has received considerable attention due to its health implications. In this study, the water-soluble oxidative potential $\left(\mathrm{OP}^{\mathrm{WS}}\right)$ of SOA generated from the photooxidation of biogenic and anthropogenic hydrocarbon precursors (isoprene, $\alpha$-pinene, $\beta$-caryophyllene, pentadecane, $m$ xylene, and naphthalene) under different reaction conditions (" $\mathrm{RO}_{2}+\mathrm{HO}_{2}$ " vs. " $\mathrm{RO}_{2}+\mathrm{NO}$ " dominant, dry vs. humid) was characterized using dithiothreitol (DTT) consumption. The measured intrinsic OP ${ }^{\mathrm{WS}-\mathrm{DTT}}$ values ranged from 9 to $205 \mathrm{pmol} \mathrm{min}^{-1} \mu \mathrm{g}^{-1}$ and were highly dependent on the specific hydrocarbon precursor, with naphthalene and isoprene SOA generating the highest and lowest OPWS-DTT values, respectively. Humidity and $\mathrm{RO}_{2}$ fate affected $\mathrm{OP}$ WS-DTT in a hydrocarbon-specific manner, with naphthalene SOA exhibiting the most pronounced effects, likely due to the formation of nitroaromatics. Together, these results suggest that precursor identity may be more influential than reaction condition in determining SOA oxidative potential, demonstrating the importance of sources, such as incomplete combustion, to aerosol toxicity. In the context of other PM sources, all SOA systems, with the exception of naphthalene SOA, were less DTT active than ambient sources related to incomplete combustion, including diesel and gasoline combustion as well as biomass burning. Finally, naphthalene SOA was as DTT active as biomass burning aerosol, which was found to be the most DTT-active OA source in a previous ambient
\end{abstract}

study. These results highlight a need to consider SOA contributions (particularly from anthropogenic hydrocarbons) to health effects in the context of hydrocarbon emissions, SOA yields, and other PM sources.

\section{Introduction}

Numerous epidemiological studies have found associations between elevated particulate matter (PM) concentrations and increased incidences of cardiopulmonary disease, including increases in lung cancer, asthma, chronic obstructive pulmonary disease, arrhythmia, and ischemic heart disease (Li et al., 2008; Pope III and Dockery, 2006; Brunekreef and Holgate, 2002; Dockery et al., 1993; Hoek et al., 2013; Anderson et al., 2011; Pope et al., 2002). Furthermore, ambient PM pollution ranked among the top 10 global risk factors in the 2010 Global Burden of Disease Study, with significant contributions from cardiopulmonary diseases and lower respiratory infections (Lim et al., 2012). Recent epidemiological studies have also found an association between particle oxidative potential and various cardiopulmonary health endpoints (Bates et al., 2015; Fang et al., 2016; Yang et al., 2016; Weichenthal et al., 2016). Furthermore, results from toxicology studies suggest that PM-induced oxidant production, including reactive oxygen and nitrogen species (ROS/RNS), is a possible mechanism by which PM exposure results in adverse health effects (Li et al., 2003a; Tao et al., 2003; Castro and Freeman, 
2001; Gurgueira et al., 2002). These species can initiate inflammatory cascades, which may ultimately lead to oxidative stress and cellular damage (Wiseman and Halliwell, 1996; Hensley et al., 2000). Prolonged stimulation of inflammatory cascades may also lead to chronic inflammation, for which there is a well-established link between chronic inflammation and cancer (Philip et al., 2004). Collectively, these findings suggest a possible link between PM exposure and epidemiologically associated health endpoints since PM can contain ROS/RNS and generate ROS/RNS via redox reactions and by inducing cellular pathways that produce ROS/RNS.

Chemical assays in which an antioxidant is used to simulate redox reactions that would occur in biological systems have been developed to study the oxidative potential of PM samples (Kumagai et al., 2002; Cho et al., 2005). In these assays, redox-active species in PM samples catalyze electron transfer from the antioxidant (dithiothreitol, DTT; ascorbic acid, AA; etc.) to oxygen, and antioxidant decay provides a measure of the concentration of redox-active species in the sample (Fang et al., 2015b). These assays have been utilized extensively to characterize ambient PM samples, and source apportionment regressions have been applied to DTT activity results to identify PM sources that may be detrimental to health (Bates et al., 2015; Fang et al., 2015a; Verma et al., 2014, 2015a). Results from these regressions, as well as inhalation and exposure studies, suggest that organic carbon constituents may play a significant role in PM-induced health effects (Li et al., 2003b; Kleinman et al., 2005; Hamad et al., 2015; Verma et al., 2015b). In particular, humic-like substances (HULIS) and oxygenated polyaromatic hydrocarbons (PAHs) have been shown to contribute significantly to the redox activity of water-soluble PM samples (Verma et al., 2012, 2015a, b; Dou et al., 2015; Lin and Yu, 2011). Recently, Tuet et al. (2016) also showed that there is a significant correlation between intracellular ROS/RNS production and organic species (water-soluble organic carbon and brown carbon) for summer ambient samples, which suggests that photochemically driven secondary organic aerosols (SOA) may be important in PM-induced oxidative stress.

Many prior studies have focused on the health effects of primary emissions, such as PM directly emitted from diesel and gasoline engines (Bai et al., 2001; Kumagai et al., 2002; McWhinney et al., 2013a; Turner et al., 2015). Conversely, few studies have explored the potential health implications of SOA, which are formed from the oxidation of volatile organic compounds (VOCs; McWhinney et al., 2013b; Rattanavaraha et al., 2011; Kramer et al., 2016; Lund et al., 2013; McDonald et al., 2010, 2012; Baltensperger et al., 2008; Arashiro et al., 2016; Platt et al., 2014), even though field studies have shown that SOA often dominate over primary aerosols even in urban environments (Zhang et al., 2007; Jimenez et al., 2009; Ng et al., 2010). The few studies that exist focus on SOA generated from a single class of hydrocarbon precursor or on SOA formed in a simulated urban background (Kramer et al., 2016; McWhinney et al., 2013b;
Rattanavaraha et al., 2011; Arashiro et al., 2016; McDonald et al., 2012). While studies on oxidative potential have shown that SOA is indeed redox active, the combined range of oxidative potentials observed for individual SOA systems is quite large and remains unexplored (McWhinney et al., 2013b; Kramer et al., 2016). Furthermore, results from cellular exposure studies are inconclusive, with some studies finding significant response from SOA exposure and others finding little to no response. The exposure dose also differed from study to study, which may result in inconclusive results. This also highlights a need to consider dose-response relationships as demonstrated recently in Tuet et al. (2016). Comparisons between the observed cellular endpoints from exposure to SOA formed from individual precursors are also lacking (Baltensperger et al., 2008; Lund et al., 2013; McDonald et al., 2010, 2012; Arashiro et al., 2016). As such, there is a lack of perspective in terms of different individual SOA systems and their contributions to PM-induced health effects, making it unclear whether certain responses are indeed toxic for a range of sources and subtypes of PM. However, as cellular assays and animal inhalation experiments are more complex, a systematic study on the oxidative potential of individual SOA systems may be warranted first.

In the present study, the water-soluble oxidative potential of SOA generated from various precursors under different reaction conditions was measured using the DTT assay (henceforth referred to as $\mathrm{OP}^{\mathrm{WS}-\mathrm{DTT}}$ ). While numerous cell-free assays have been developed to measure oxidative potential, the DTT assay is well-suited for the purposes of this study due to its proven sensitivity to organic carbon constituents and its correlation with organic carbon (Janssen et al., 2014; Visentin et al., 2016). Furthermore, there are many previous studies reporting the DTT activities of laboratory-generated SOA and ambient samples for comparison purposes (Kramer et al., 2016; Bates et al., 2015; McWhinney et al., 2013a, b; Verma et al., 2015a; Xu et al., 2015a, b; Fang et al., 2015b; $\mathrm{Lu}$ et al., 2014). VOCs were chosen to represent the major classes of compounds known to produce SOA upon oxidation by atmospheric oxidants and to include precursors of both anthropogenic and biogenic origins (Table S1 in the Supplement). Biogenic precursors include isoprene, $\alpha$-pinene, and $\beta$-caryophyllene, while anthropogenic precursors include pentadecane, $m$-xylene, and naphthalene. Isoprene was chosen since it is the most abundant non-methane hydrocarbon, with estimated global emissions around $500 \mathrm{Tg} \mathrm{yr}^{-1}$ (Guenther et al., 2006). $\alpha$-pinene and $\beta$-caryophyllene were chosen as representative, well-studied monoterpenes and sesquiterpenes, respectively. Both classes of compounds contribute significantly to ambient aerosol (Eddingsaas et al., 2012; Hoffmann et al., 1997; Tasoglou and Pandis, 2015; Goldstein and Galbally, 2007). $\alpha$-pinene emissions $\left(\sim 50 \mathrm{Tg} \mathrm{yr}^{-1}\right)$ are also on the same order of global anthropogenic emissions ( $\sim 110 \mathrm{Tg} \mathrm{yr}^{-1}$; Guenther et al., 1993; Piccot et al., 1992). Similarly, anthropogenic precursors were chosen to include a long-chain alkane (pentadecane), a single-ring aromatic ( $m$ - 
Table 1. Experimental conditions.

\begin{tabular}{|c|c|c|c|c|c|}
\hline Experiment & Compound & $\begin{array}{l}\mathrm{OH} \\
\text { precursor }\end{array}$ & $\begin{array}{r}\text { Relative } \\
\text { humidity }(\%)\end{array}$ & $\begin{array}{r}{[\mathrm{HC}]_{0}} \\
(\mathrm{ppb})\end{array}$ & $\begin{array}{r}{[\mathrm{SOA}]^{\mathrm{c}}} \\
\left(\mu \mathrm{g} \mathrm{m}^{-3}\right)\end{array}$ \\
\hline $1^{\mathrm{a}}$ & isoprene & $\mathrm{H}_{2} \mathrm{O}_{2}$ & $<5 \%$ & 97 & 5.73 \\
\hline $2^{\mathrm{a}}$ & $\alpha$-pinene & $\mathrm{H}_{2} \mathrm{O}_{2}$ & $<5 \%$ & 191 & 119 \\
\hline $3^{\mathrm{a}}$ & $\beta$-caryophyllene & $\mathrm{H}_{2} \mathrm{O}_{2}$ & $<5 \%$ & 36 & 221 \\
\hline $4^{\mathrm{a}}$ & pentadecane & $\mathrm{H}_{2} \mathrm{O}_{2}$ & $<5 \%$ & 106 & 9.71 \\
\hline $5^{\mathrm{a}}$ & $m$-xylene & $\mathrm{H}_{2} \mathrm{O}_{2}$ & $<5 \%$ & 450 & 89.3 \\
\hline $6^{\mathrm{a}}$ & naphthalene & $\mathrm{H}_{2} \mathrm{O}_{2}$ & $<5 \%$ & 178 & 128 \\
\hline 7 & isoprene & $\mathrm{H}_{2} \mathrm{O}_{2}$ & $<5 \%$ b & 97 & 17.1 \\
\hline 8 & $\alpha$-pinene & $\mathrm{H}_{2} \mathrm{O}_{2}$ & $40 \%$ & 334 & 154 \\
\hline 9 & $\beta$-caryophyllene & $\mathrm{H}_{2} \mathrm{O}_{2}$ & $42 \%$ & 63 & 230 \\
\hline 10 & pentadecane & $\mathrm{H}_{2} \mathrm{O}_{2}$ & $45 \%$ & 106 & 23.5 \\
\hline 11 & $m$-xylene & $\mathrm{H}_{2} \mathrm{O}_{2}$ & $45 \%$ & 450 & 13.9 \\
\hline 12 & naphthalene & $\mathrm{H}_{2} \mathrm{O}_{2}$ & $44 \%$ & 431 & 132 \\
\hline 13 & isoprene & HONO & $<5 \%$ & 970 & 148 \\
\hline 14 & $\alpha$-pinene & HONO & $<5 \%$ & 174 & 166 \\
\hline 15 & $\beta$-caryophyllene & HONO & $<5 \%$ & 21 & 80.8 \\
\hline 16 & pentadecane & HONO & $<5 \%$ & 74 & 35.7 \\
\hline 17 & $m$-xylene & HONO & $<5 \%$ & 431 & 153 \\
\hline 18 & naphthalene & HONO & $<5 \%$ & 145 & 142 \\
\hline
\end{tabular}

xylene), and a poly-aromatic (naphthalene). These classes of compounds are emitted as products of incomplete combustion (Robinson et al., 2007; Jia and Batterman, 2010; Bruns et al., 2016) and have been shown to have considerable SOA yields (e.g., Chan et al., 2009; Ng et al., 2007b; Lambe et al., 2011). In addition to precursor identity, the effects of humidity (dry vs. humid) and $\mathrm{NO}_{x}$ (differing peroxy radical $\left(\mathrm{RO}_{2}\right)$ fates, $\mathrm{RO}_{2}+\mathrm{HO}_{2}$ vs. $\mathrm{RO}_{2}+\mathrm{NO}$ ) on OP ${ }^{\mathrm{WS}-\mathrm{DTT}}$ were investigated because these conditions have been shown to affect the chemical composition and mass loading of formed SOA (Chhabra et al., 2010, 2011; Eddingsaas et al., 2012; Ng et al., 2007a, b; Loza et al., 2014; Chan et al., 2009; Boyd et al., 2015). Finally, intrinsic OPWS-DTT was compared with bulk aerosol composition, specifically elemental ratios, to investigate whether there is a link between OPWS-DTT and aerosol composition.

\section{Methods}

\subsection{Chamber experiments}

SOA from the photooxidation of biogenic and anthropogenic VOCs were generated in the Georgia Tech Environmental Chamber (GTEC) facility. Details of the facility are described elsewhere (Boyd et al., 2015). Briefly, the facility consists of two $12 \mathrm{~m}^{3}$ Teflon chambers suspended inside a $6.4 \mathrm{~m} \times 3.7 \mathrm{~m}(21 \mathrm{ft} \times 12 \mathrm{ft})$ temperature-controlled enclosure surrounded by black lights (Sylvania 24922) and natural sunlight fluorescent lamps (Sylvania 24477). Multiple sam- pling ports from each chamber allow for gas- and aerosolphase measurements as well as introduction of reagents. Gasphase measurements include $\mathrm{O}_{3}, \mathrm{NO}_{2}$, and $\mathrm{NO}_{x}$ concentrations as measured by an $\mathrm{O}_{3}$ analyzer (Teledyne T400), a cavity-attenuated phase shift (CAPS) $\mathrm{NO}_{2}$ monitor (Aerodyne), and a chemiluminescence $\mathrm{NO}_{x}$ monitor (Teledyne 200EU), respectively. Additionally, a gas chromatographyflame ionization detector (GC-FID, Agilent 7890A) was used to monitor hydrocarbon decay and estimate hydroxyl radical $(\mathrm{OH})$ concentration. In terms of aerosol-phase measurements, aerosol volume concentrations and distributions were measured using a scanning mobility particle sizer (SMPS, TSI), while bulk aerosol composition was determined using a high-resolution time-of-flight aerosol mass spectrometer (HR-ToF-AMS, Aerodyne; henceforth referred to as the AMS) (DeCarlo et al., 2006). AMS data were analyzed using the data analysis toolkits SQUIRREL (v. 1.57) and PIKA (v. 1.16). Elemental ratios $(\mathrm{O}: \mathrm{C}, \mathrm{H}: \mathrm{C}$, and $\mathrm{N}: \mathrm{C})$ were obtained using the method outlined by Canagaratna et al. (2015) and were used to calculate the average carbon oxidation state $\left(\overline{\mathrm{OS}}_{\mathrm{c}}\right)$ (Kroll et al., 2011). Temperature and relative humidity $(\mathrm{RH})$ were monitored using a hydro-thermometer (Vaisala HMP110).

Experimental conditions, given in Table 1, were designed to probe the effects of humidity, $\mathrm{RO}_{2}$ fate, and precursor hydrocarbon on OP ${ }^{\mathrm{WS}-\mathrm{DTT}}$. All experiments were performed at $\sim 25^{\circ} \mathrm{C}$ under dry $(\mathrm{RH}<5 \%)$ or humid $(\mathrm{RH} \sim 45 \%)$ conditions. Prior to each experiment, the chambers were flushed with pure air for $\sim 24 \mathrm{~h}$. For humid experiments, the cham- 
bers were also humidified by means of a bubbler filled with deionized (DI) water during this time. Seed aerosol was then injected by atomizing a $15 \mathrm{mM}\left(\mathrm{NH}_{4}\right)_{2} \mathrm{SO}_{4}$ seed solution (Sigma Aldrich) until the seed concentration was approximately $20 \mu \mathrm{g} \mathrm{m}^{-3}$. It is noted that for experiment 7 (isoprene SOA under $\mathrm{RO}_{2}+\mathrm{HO}_{2}$-dominant, "humid" conditions), experimental conditions deviated due to extremely low SOA mass yields. For this experiment, an acidic seed solution $\left(8 \mathrm{mM} \mathrm{MgSO}_{4}\right.$ and $16 \mathrm{mM} \mathrm{H}_{2} \mathrm{SO}_{4}$ ) was used under dry conditions to promote SOA formation via the IEPOX (isoprene epoxydiols) uptake pathway, which has a higher SOA mass yield compared to the IEPOX $+\mathrm{OH}$ pathway and contributes significantly to ambient OA (Surratt et al., 2010; Lin et al., 2012).

Once the seed concentration stabilized, hydrocarbon was added by injecting a known volume of hydrocarbon solution (isoprene, $99 \% ; \alpha$-pinene, $\geq 99 \% ; \beta$-caryophyllene, $>98.5 \%$; pentadecane, $\geq 99 \%$; $m$-xylene, $\geq 99 \%$; naphthalene, $99 \%$ (Sigma Aldrich)) into a glass bulb and passing zero air at $5 \mathrm{~L} \mathrm{~min}^{-1}$ over the solution until fully evaporated $(\sim 10 \mathrm{~min})$. For pentadecane and $\beta$-caryophyllene, the glass bulb was gently heated to ensure full evaporation (Tasoglou and Pandis, 2015). Naphthalene was injected by passing pure air over the solid, as outlined in previous studies (Chan et al., 2009). After hydrocarbon injection, $\mathrm{OH}$ precursor was added to the chamber. Experiments were conducted under various $\mathrm{NO}_{x}$ conditions where different $\mathrm{RO}_{2}$ reaction pathways prevailed. For $\mathrm{RO}_{2}+\mathrm{HO}_{2}$ experiments, hydrogen peroxide $\left(\mathrm{H}_{2} \mathrm{O}_{2}\right)$ was used as the $\mathrm{OH}$ precursor. $\mathrm{H}_{2} \mathrm{O}_{2}(50 \%$ aqueous solution, Sigma Aldrich) was injected using the method described for hydrocarbon injection to achieve an $\mathrm{H}_{2} \mathrm{O}_{2}$ concentration of $3 \mathrm{ppm}$, which yielded $\mathrm{OH}$ concentrations on the order of $10^{6}$ molec $\mathrm{cm}^{-3}$. For $\mathrm{RO}_{2}+\mathrm{NO}$ experiments, nitrous acid (HONO) was used as the $\mathrm{OH}$ precursor. $\mathrm{HONO}$ was prepared by adding $10 \mathrm{~mL}$ of $1 \%$ wt aqueous $\mathrm{NaNO}_{2}$ (VWR International) dropwise into $20 \mathrm{~mL}$ of $10 \%$ wt $\mathrm{H}_{2} \mathrm{SO}_{4}$ (VWR International) in a glass bulb. Zero air was then passed over the solution to introduce HONO into the chamber (Chan et al., 2009; Kroll et al., 2005). Photolysis of HONO yielded $\mathrm{OH}$ concentrations on the order of $10^{7}$ molec $\mathrm{cm}^{-3}$. NO and $\mathrm{NO}_{2}$ were also formed as byproducts of HONO synthesis. Once all the $\mathrm{H}_{2} \mathrm{O}_{2}$ evaporated $\left(\mathrm{RO}_{2}+\mathrm{HO}_{2}\right.$ experiments) or $\mathrm{NO}_{x}$ concentrations stabilized $\left(\mathrm{RO}_{2}+\mathrm{NO}\right.$ experiments), the UV lights were turned on to initiate photooxidation.

\subsection{Aerosol collection and extraction}

Aerosol samples were collected onto $47 \mathrm{~mm}$ Teflon $^{\mathrm{TM}}$ filters $(0.45 \mu \mathrm{m}$ pore size, Pall Laboratory) for approximately $1.5 \mathrm{~h}$ at a flow rate of $28 \mathrm{~L} \mathrm{~min}^{-1}$. For each experiment, two filters (front filter and backing filter) were loaded in series to account for possible sampling artifacts (Conny and Slater, 2002). Total mass collected was determined by integrating the SMPS volume concentration as a function of time over the filter collection period and using the total volume of air

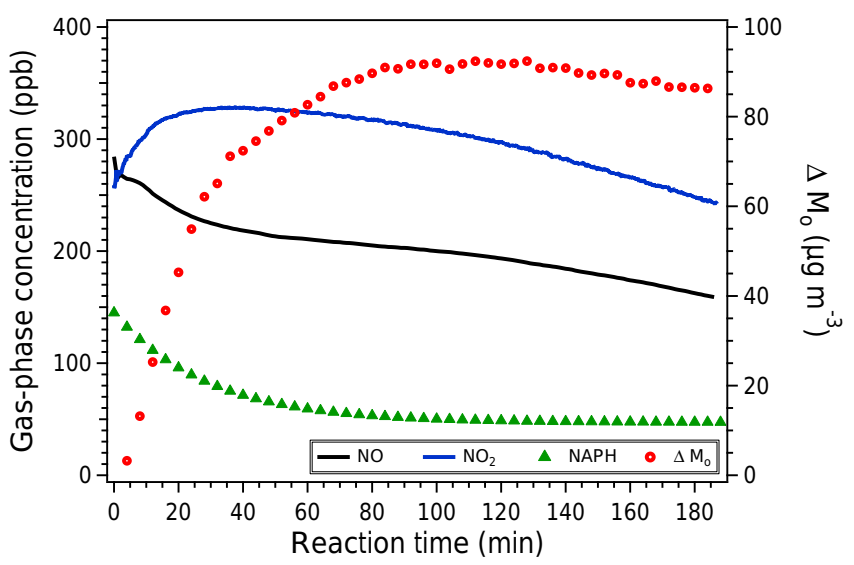

Figure 1. Typical reaction profile for a chamber experiment under $\mathrm{RO}_{2}+\mathrm{NO}$-dominant conditions. $\mathrm{NO}$ and $\mathrm{NO}_{2}$ concentrations were monitored by CAPS $\mathrm{NO}_{2}$ and chemiluminescence $\mathrm{NO}_{x}$ monitors, respectively. Hydrocarbon decay was monitored using GCFID, while initial hydrocarbon (naphthalene) concentrations were determined using the chamber volume and mass of hydrocarbon injected. Aerosol mass concentrations were determined using volume concentrations obtained from SMPS and assuming an aerosol density of $1 \mathrm{~g} \mathrm{~cm}^{-3}$. While typical SOA density is about $1.4 \mathrm{~g} \mathrm{~cm}^{-3}$, it varies with hydrocarbon precursor identity and reaction conditions, and a density between $\sim 1.0$ and $1.6 \mathrm{~g} \mathrm{~cm}^{-3}$ has been reported in previous studies ( $\mathrm{Ng}$ et al., 2006, 2007a, b; Chan et al., 2009; Tasoglou and Pandis, 2015; Bahreini et al., 2005). The use of a density of $1 \mathrm{~g} \mathrm{~cm}^{-3}$ is to facilitate easier comparisons with past and future studies. Results from future studies can be scaled accordingly for comparison with the current work. Mass concentrations have been corrected for particle wall loss (Nah et al., 2016).

collected. Volume concentrations were integrated using timedependent data. Background filters containing seed and an $\mathrm{OH}$ precursor $\left(\mathrm{H}_{2} \mathrm{O}_{2}\right.$ or $\left.\mathrm{HONO}\right)$ only at experimental conditions were also collected to account for potential $\mathrm{H}_{2} \mathrm{O}_{2}$ or HONO uptake, which may influence oxidative potential. Collected filter samples were placed in sterile petri dishes, sealed with Parafilm $\mathrm{M}^{\circledR}$, and stored at $-20^{\circ} \mathrm{C}$ until extraction and analysis (Fang et al., 2015b). Prior to determining OPWS-DTT, collected particles were extracted in DI water by submerging the filter and sonicating for $1 \mathrm{hr}$ using an Ultrasonic Cleanser (VWR International; Fang et al., 2015a). Sonication steps were performed in $30 \mathrm{~min}$ intervals with water replacement after each interval to reduce bath temperature. After sonication, extracts were filtered using $0.45 \mu \mathrm{m}$ PTFE (polytetrafluoroethylene) syringe filters (Fisherbrand ${ }^{\mathrm{TM}}$ ) to remove insoluble material (Fang et al., 2015b). All filter samples were extracted within 1-2 days of collection and analyzed immediately following extraction. 


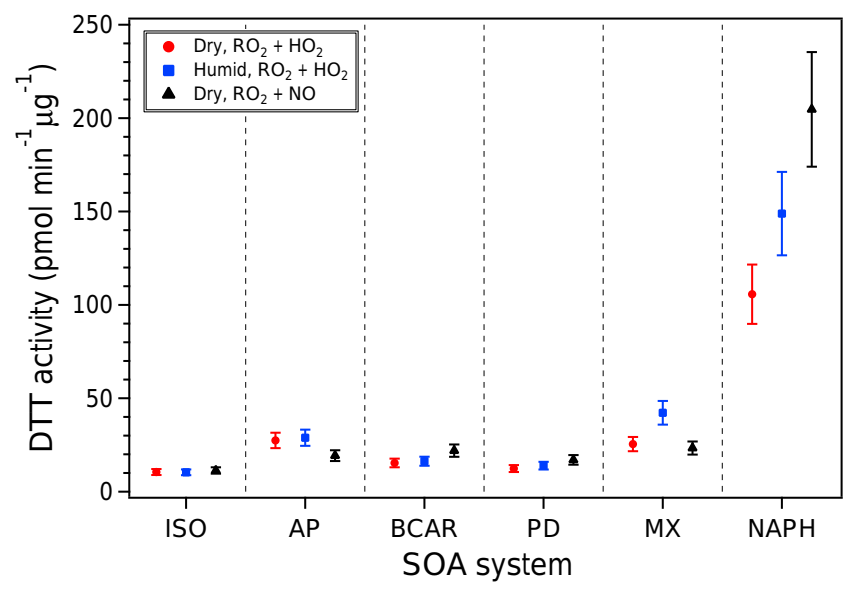

Figure 2. Intrinsic DTT activities for SOA generated from various hydrocarbon precursors (ISO: isoprene, AP: $\alpha$-pinene, BCAR: $\beta$ caryophyllene, PD: pentadecane, MX: $m$-xylene, and NAPH: naphthalene) under various conditions (red circles: dry, $\mathrm{RO}_{2}+\mathrm{HO}_{2}$; blue squares: humid, $\mathrm{RO}_{2}+\mathrm{HO}_{2}$; and black triangles: dry, $\mathrm{RO}_{2}+\mathrm{NO}$ ). Dry $\mathrm{RO}_{2}+\mathrm{HO}_{2}$ experiments were repeated to ensure reproducibility in SOA generation and collection. Error bars represent a $15 \%$ coefficient of variation (Fang et al., 2015b).

\subsection{Oxidative potential}

The decay of DTT, a chemical species that reacts with redoxactive species in a sample via electron transfer reactions, was used as a measure of oxidative potential (Cho et al., 2005; Kumagai et al., 2002). The intrinsic OPWS-DTT of aerosol samples, as well as method blanks and positive controls (9,10-phenanthraquinone), was determined using a semiautomated DTT system. Specifics of the high-throughput system are detailed in Fang et al. (2015b) Briefly, the method consisted of three main steps: (1) oxidation of DTT by redoxactive species in the sample, (2) reaction of residual DTT with DTNB (5,5'-dithiobis(2-nitrobenzoic acid)) to form 2nitro-5-mercaptobenzoic acid (TNB), repeated at specific time intervals, and (3) measurement of TNB to determine DTT consumption. After each time interval and between samples, the system was flushed with DI water.

\section{Results and discussion}

\subsection{Laboratory-generated aerosol}

Over the course of each experiment, gas and aerosol composition was continuously monitored. A typical time series for $\mathrm{NO}, \mathrm{NO}_{2}$, gas-phase hydrocarbon concentration, and aerosol mass concentration is shown in Fig. 1 for naphthalene photooxidation under $\mathrm{RO}_{2}+\mathrm{NO}$-dominant reaction conditions. Hydrocarbon decay was monitored using GC-FID, while initial gas-phase hydrocarbon concentrations were determined using the chamber volume and mass of hydrocarbon in-

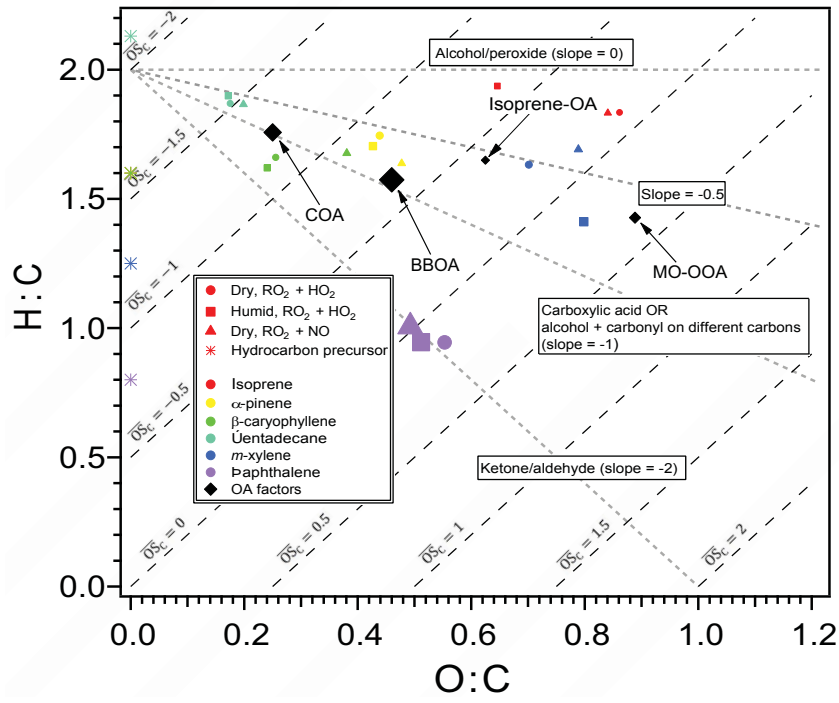

Figure 3. Van Krevelen plot for various SOA systems. Data points are colored by SOA system (red: isoprene, yellow: $\alpha$-pinene, green: $\beta$-caryophyllene, light blue: pentadecane, blue: $m$-xylene, and purple: naphthalene), shaped according to reaction conditions (circle: dry, $\mathrm{RO}_{2}+\mathrm{HO}_{2}$; square: humid, $\mathrm{RO}_{2}+\mathrm{HO}_{2}$; and triangle: dry, $\mathrm{RO}_{2}+\mathrm{NO}$ ), and sized by intrinsic DTT activity. OA factors resolved from PMF analysis of ambient AMS data are shown as black markers, also sized by intrinsic DTT activity. Hydrocarbon precursors are shown as stars, colored by SOA system. Specifics on site locations and factor resolution methods are described elsewhere. COA: cooking OA, BBOA: biomass burning OA, IsopreneOA: isoprene-derived OA, MO-OOA: more-oxidized oxygenated OA (Verma et al., 2015a; Xu et al., 2015a, b).

jected. Following irradiation, NO decreased due to reaction with $\mathrm{RO}_{2}$ from hydrocarbon oxidations. Nevertheless, ozone formation was suppressed owing to the high NO concentration throughout the experiment. Aerosol growth is observed shortly after initiation of photooxidation (i.e., turning on the lights) due to the efficient photolysis of HONO, which produced a high $\mathrm{OH}$ concentration on the order of $10^{7}$ molec $\mathrm{cm}^{-3}$. Once HONO was completely consumed, no further decay in the parent hydrocarbon and growth in aerosol mass were observed.

For each experiment, aerosol chemical composition was also monitored using the AMS. The average AMS mass spectra (Fig. S1 in the Supplement) for all VOC systems were consistent with those reported in previous studies (Chhabra et al., 2010, 2011). For $\mathrm{RO}_{2}+$ NO-dominant experiments, the $\mathrm{NO}^{+}: \mathrm{NO}_{2}^{+}$ratio has been used extensively in previous studies to differentiate between organic and inorganic nitrates (Farmer et al., 2010; Fry et al., 2009; Boyd et al., 2015; $\mathrm{Xu}$ et al., 2015b). The observed $\mathrm{NO}^{+}: \mathrm{NO}_{2}^{+}$ratio for all $\mathrm{RO}_{2}+$ NO-dominant experiments (4.2-6.1) was higher than that observed for inorganic (ammonium) nitrates $(\sim 2.3)$, which indicates that these peaks are likely from organic nitrates rather than inorganic nitrates. The observed range is 
also consistent with values measured in previous organic nitrate studies for similar VOC systems and ambient studies (Bruns et al., 2010; Sato et al., 2010; Xu et al., 2015b). Elemental ratios $(\mathrm{O}: \mathrm{C}, \mathrm{H}: \mathrm{C}$, and $\mathrm{N}: \mathrm{C})$ were also obtained for each SOA system using the AMS. The aerosol systems investigated span a wide range of $\mathrm{O}: \mathrm{C}$ ratios, as observed in previous laboratory and field studies (Chhabra et al., 2011; Lambe et al., 2011; Jimenez et al., 2009; Ng et al., 2010).

\subsection{Effect of hydrocarbon precursor and reaction condition on oxidative potential}

To investigate whether different types of SOA differ in toxicity, the OPWS-DTT , a measure of the concentration of redoxactive species present in a sample, was measured for SOA generated from six VOCs under three conditions (see Table 1 for specifics). The blank-corrected OP ${ }^{\text {WS-DTT }}$ values, represented on a per mass $(\mu \mathrm{g})$ basis, are shown in Fig. 2. Uncertainties associated with OP ${ }^{\text {WS-DTT }}$ determination were approximated using a $15 \%$ coefficient of variation, in accordance with previous studies using the same semiautomated system (Fang et al., 2015b). The OPWS-DTT values of all backing filters and background filters were also measured and found to be within the uncertainty for blank Teflon filters, which indicates that there were no observable sampling artifacts, gaseous absorption onto Teflon filters, or $\mathrm{H}_{2} \mathrm{O}_{2}$ or HONO uptake onto seed particles.

Overall, it is clear that the hydrocarbon precursor identity influenced OPWS-DTT , with naphthalene having the highest intrinsic DTT activity (Fig. 2). All other hydrocarbon precursors investigated produced SOA with relatively low intrinsic OPWS-DTT $\left(\sim 9-45 \mathrm{pmol} \mathrm{min}^{-1} \mu \mathrm{g}^{-1}\right)$. For isoprene, the SOA in this study was generated through different reaction pathways, including isoprene photooxidation under different $\mathrm{RO}_{2}$ fates and IEPOX reactive uptake to acidic seed particles. Although these different conditions produced different products and SOA compositions (Xu et al., 2014; Surratt et al., 2010; Chan et al., 2010), the OP ${ }^{\mathrm{WS}-\mathrm{DTT}}$ is very similar. It is important to note that the intrinsic OPWS-DTT values for SOA generated under all conditions in this study are in agreement with the isoprene-derived OA factor resolved from positive matrix factorization (PMF) analysis of ambient AMS data (Fig. 4; Xu et al., 2015a, b; Verma et al., 2015a). The isoprene-derived OA from ambient measurements is largely attributed to IEPOX uptake, but it possibly contains some contribution from other isoprene oxidation pathways (Xu et al., 2015a, b). The similarity between laboratory-generated and ambient isoprene SOA suggests that isoprene SOA may have low OPWS-DTT regardless of reaction conditions. A previous laboratory chamber study by Kramer et al. (2016) also measured the DTT activity of isoprene SOA produced via different pathways, including SOA formed from direct photooxidation of isoprene. It was found that isoprene SOA formed under "high- $\mathrm{NO}_{x}$ " conditions was more DTT active than that formed under "low- $\mathrm{NO}_{x}$ " conditions. These re- sults are in contrast with those obtained in this study, where the OPWS-DTT of isoprene SOA was similar regardless of reaction condition. However, we caution that (1) the SOA measured in Kramer et al. (2016) was formed under different experimental conditions, and (2) they utilized a different method for measuring DTT consumption (i.e., different extraction solvent, different initial DTT concentration, different method for quantifying DTT activity); therefore, the results from their study and ours may not be directly comparable. For instance, for isoprene photooxidation experiments, the low- $\mathrm{NO}_{x}$ conditions in Kramer et al. (2016) corresponded to " $5 \mathrm{ppm}$ isoprene and $200 \mathrm{ppb} \mathrm{NO}$ ", where the reaction regime was largely defined by the $\mathrm{VOC} / \mathrm{NO}_{x}$ ratio. It has been shown previously that SOA formed under the same VOC / $\mathrm{NO}_{x}$ conditions can be drastically different and the use of this metric might not necessarily reflect the actual peroxy radical fate (Ng et al., 2007b; Kroll and Seinfeld, 2008; Wennberg, 2013). In our study, the low- $\mathrm{NO}_{x}$ experimental condition is defined by the fate of peroxy radicals directly, i.e., no $\mathrm{NO}_{x}$ added, but with the presence of $\mathrm{H}_{2} \mathrm{O}_{2}$ to enhance the $\mathrm{RO}_{2}+\mathrm{HO}_{2}$ reaction pathway, which is dominant in ambient environments when $\mathrm{NO}_{x}$ levels are low.

$\alpha$-pinene, $\beta$-caryophyllene, and pentadecane produced low OPWS-DTT across all conditions explored in this study (Fig. 2). Specifically, the SOA formed under different reaction conditions do not appear to have significantly different OP WS-DTT , even though different $\mathrm{NO}_{x}$ conditions have been shown to affect SOA loading and composition due to competing $\mathrm{RO}_{2}$ chemistry (Chan et al., 2009; Eddingsaas et al., 2012; Loza et al., 2014; Ng et al., 2007a). For instance, under conditions that favor $\mathrm{RO}_{2}+\mathrm{NO}$, organic nitrates are formed, whereas under conditions that favor $\mathrm{RO}_{2}+\mathrm{HO}_{2}$, organic peroxides are the predominant products. In this study, the formation of organic nitrates is evident in the $\mathrm{RO}_{2}+\mathrm{NO}$ experiments with the relatively higher $\mathrm{NO}^{+}: \mathrm{NO}_{2}^{+}$ratio in the AMS mass spectra. It is possible that neither the organic peroxides or organic nitrates formed from the oxidation of these precursors are highly redox active, such that the overall OPWS-DTT is similar even though the products differ. Further studies are required to establish this.

Similarly, the OPWS-DTT of SOA formed from $m$-xylene under conditions that favor different $\mathrm{RO}_{2}$ fates were not significantly different. Since OPWS-DTT is intended as a measure of redox activity, the reaction products' ability to participate in electron transfer may explain this lack of difference (e.g., lack of conjugated systems and associated pi bonds with unbound electrons). Under both $\mathrm{RO}_{2}+\mathrm{HO}_{2}$ and $\mathrm{RO}_{2}+\mathrm{NO}$ pathways, a large number of $m$-xylene oxidation products do not retain the aromatic ring (Vivanco and Santiago, 2010; Jenkin et al., 2003). Therefore, these products may have similar OPWS-DTT as reaction products of $\alpha$ pinene, $\beta$-caryophyllene, and pentadecane, which also do not contain an aromatic ring. Under humid conditions, aerosols formed from the oxidation of $m$-xylene were more DTT active than those formed under dry conditions. The AMS mass 


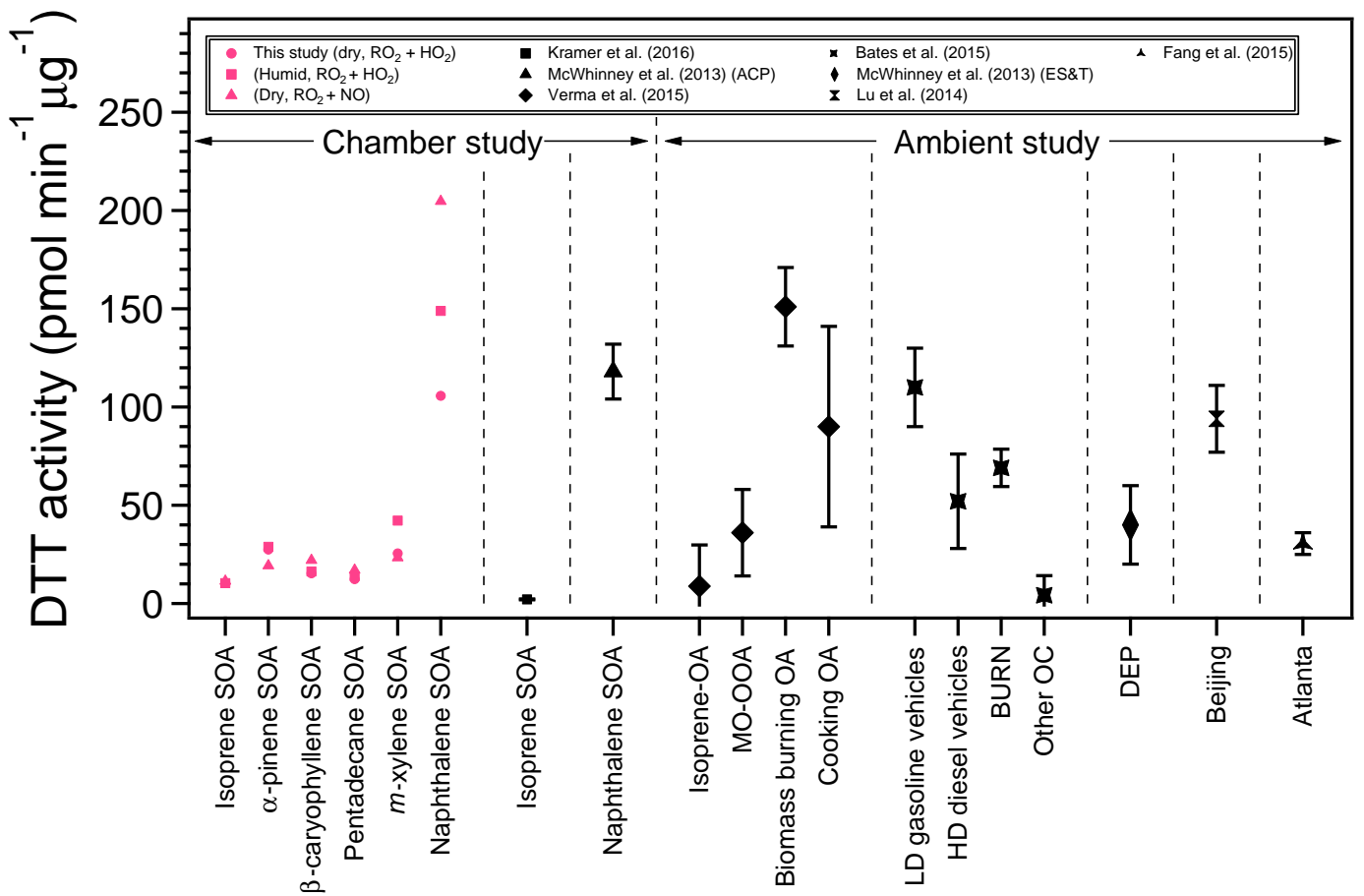

Figure 4. Intrinsic DTT activities for chamber SOA, various PM subtypes resolved from ambient data, and diesel exhaust particles. It should be noted that the DTT activity for isoprene SOA in Kramer et al. (2016) was determined using a different DTT method and may not be directly comparable. All other studies shown used the method outlined in Cho et al. (2005). DTT activities obtained in this study are shaped by reaction condition (circle: dry, $\mathrm{RO}_{2}+\mathrm{HO}_{2}$; square: humid, $\mathrm{RO}_{2}+\mathrm{HO}_{2}$; triangle: dry, $\mathrm{RO}_{2}+\mathrm{NO}$ ). Specifics on site locations and factor resolution methods are described elsewhere. DTT activities for Beijing and Atlanta are averages obtained across multiple seasons. Isoprene-OA: isoprene-derived OA, MO-OOA: more-oxidized oxygenated OA, BBOA: biomass burning OA, COA: cooking OA, LDGV: light-duty gasoline vehicles, HDDV: heavy-duty diesel vehicles, BURN: biomass burning, DEP: diesel exhaust particles (Kramer et al., 2016; McWhinney et al., 2013b; Verma et al., 2015a; Bates et al., 2015; McWhinney et al., 2013a; Xu et al., 2015a, b; Lu et al., 2014; Fang et al., 2015b).

spectra for aerosol formed under humid conditions also differs notably for several characteristic fragments (Fig. S2), which may explain the difference observed in OPWS-DTT. More specifically, $m / z 44$, which serves as an indication of oxidation (O:C ratio) ( $\mathrm{Ng}$ et al., 2010), is very different for this experiment (dry signal: 0.098 vs. humid signal: 0.15 ). It is possible that the degree of oxidation may be an important factor for SOA formed from the same hydrocarbon, and systematic chamber studies investigating changes in $\mathrm{O}: \mathrm{C}$ for SOA formed from a single hydrocarbon precursor would be valuable. Previous studies involving the effect of humidity on SOA composition also yield mixed results, with some finding significant changes in SOA composition and yields (Nguyen et al., 2011; Wong et al., 2015; Healy et al., 2009; Stirnweis et al., 2016) and others reporting little difference (Boyd et al., 2015; Edney et al., 2000; Cocker et al., 2001). Humidity effects are therefore highly hydrocarbon-dependent. Further study into the specific oxidation mechanisms and products in the photooxidation of aromatic hydrocarbon under dry and humid conditions may be warranted to understand the difference in DTT activity.
For naphthalene, the OPWS-DTT measured for SOA generated under dry, $\mathrm{RO}_{2}+\mathrm{HO}_{2}$-dominant conditions is in agreement with that measured by McWhinney et al. (2013b) (Fig. 4), which generated naphthalene SOA under similar chamber conditions using the same $\mathrm{OH}$ radical precursor. These values should be directly comparable since the same standard method described by Cho et al. (2005) was used to obtain the oxidative potentials in both McWhinney et al. (2013b) and this study. The OPWS-DTT of naphthalene aerosol also appears to be strongly influenced by humidity and $\mathrm{RO}_{2}$ fate (Fig. 2), with higher toxicities observed for aerosol formed under both humid and $\mathrm{RO}_{2}+\mathrm{NO}$-dominant conditions. The effect of $\mathrm{RO}_{2}$ fate may be explained by the different products known to form from $\mathrm{RO}_{2}+\mathrm{HO}_{2}$ and $\mathrm{RO}_{2}+\mathrm{NO}$ reaction pathways. Many of the same products, including naphthoquinones and all of the ring-opening derivatives of 2-formylcinnamaldehyde, are formed under both reaction conditions (Kautzman et al., 2010). Naphthoquinones are also known to be DTT active and have been shown to account for approximately $21 \%$ of the DTT activity observed for naphthalene SOA (Charrier and Anastasio, 2012; McWhinney et al., 2013b). In addition to these products, ni- 
troaromatics including nitronaphthols and nitronaphthalenes are formed under $\mathrm{RO}_{2}+\mathrm{NO}$ conditions (Kautzman et al., 2010). The nitrite group next to the aromatic ring in these products may further promote electron transfer between nitroaromatics and DTT, resulting in more DTT consumption and a higher OPWS-DTT. This effect was not observed for $m$-xylene SOA due to the formation of predominantly ringopening products (Vivanco and Santiago, 2010; Jenkin et al., 2003). The presence of an aromatic ring in SOA products may therefore be important for determining oxidative potentials, and polyaromatic precursors may yield products of substantial toxicity. This is further supported by the observation that the AMS mass spectra for highly DTT-active naphthalene SOA contain peaks at $m / z 77$ and $m / z 91$, which are indicative of aromatic phenyl and benzyl ions (Chhabra et al., 2010; McLafferty and Tureček, 1993). Additionally, peaks indicative of aromatic compounds greater than $m / z 120$ were observed with similar mass spectral features as those reported for aerosol generated from naphthalene oxidation by $\mathrm{OH}$ radicals in previous studies (Riva et al., 2015). Aromatic species are also exclusive to HULIS (Sannigrahi et al., 2006), and ambient data have shown that HULIS are a significant aerosol component contributing to OPWS-DTT (Verma et al., 2012, 2015b; Dou et al., 2015; Lin and Yu, 2011).

Bulk aerosol elemental ratios $(\mathrm{O}: \mathrm{C}, \mathrm{H}: \mathrm{C}$, and $\mathrm{N}: \mathrm{C})$ were also determined for each SOA system since different types of aerosol are known to span a wide range of $\mathrm{O}: \mathrm{C}$ (Chhabra et al., 2011; Lambe et al., 2011). All elemental ratios were stable during the filter collection period and could thus be represented by a single value. To visualize these differences in oxidation, the van Krevelen diagram was utilized (Fig. 3) because changes in the slope of data points within the van Krevelen space can provide information on SOA functionalization (Heald et al., 2010; Van Krevelen, 1950; $\mathrm{Ng}$ et al., 2011). Starting from the precursor hydrocarbon, a slope of 0 indicates addition of alcohol groups, a slope of -1 indicates addition of carbonyl and alcohol groups on separate carbons or addition of carboxylic acids, and a slope of -2 indicates addition of ketones or aldehydes. Previous studies show that both laboratory-generated and ambient OA occupy a narrow van Krevelen space with a slope of $\sim-1$ to -0.5 (Heald et al., 2010; Ng et al., 2011). Ambient data included in Fig. 3 are for different organic aerosol subtypes resolved from PMF analysis of AMS data collected in the southeastern US (Verma et al., 2015a; Xu et al., 2015a, b).

The laboratory-generated aerosols span the range of $\mathrm{H}: \mathrm{C}$ and $\mathrm{O}: \mathrm{C}$ observed in the ambient. As seen in Fig. 3 (data points sized by intrinsic OP ${ }^{\mathrm{WS}-\mathrm{DTT}}$ ), while different reaction conditions produced aerosol of differing composition (i.e., different $\mathrm{O}: \mathrm{C}$ and $\mathrm{H}: \mathrm{C}$ ), the intrinsic OPWS-DTT does not appear to be affected by these differences. On the other hand, the hydrocarbon precursor identity influences OPWS-DTT substantially. It has been shown that ambient OA from different sources can become increasingly oxidized (increasing $\mathrm{O}: \mathrm{C}$ ratio) with atmospheric aging (Jimenez et al.,
2009; Ng et al., 2011). Based on the results shown in Fig. 3, it appears that a higher $\mathrm{O}: \mathrm{C}$ ratio did not correspond to a higher OPWS-DTT. This is true for both the laboratorygenerated SOA in this study and the different OA subtypes resolved from ambient data (Verma et al., 2015a; Xu et al., 2015a, b). Nevertheless, the $\mathrm{O}: \mathrm{C}$ ratios for individual systems (i.e., SOA formed from the same hydrocarbon precursor) may affect the intrinsic OPWS-DTT. Indeed, for several SOA systems ( $\beta$-caryophyllene, pentadecane, and $m$ xylene), SOA with higher O : $\mathrm{C}$ ratios also had a higher intrinsic OPWS-DTT (Figs. 2, 3). For SOA systems formed under $\mathrm{RO}_{2}+\mathrm{NO}$-dominant conditions, $\mathrm{N}: \mathrm{C}$ ratios were also determined to investigate if there is a link between $\mathrm{N}: \mathrm{C}$ and intrinsic DTT activity (Fig. S3). Again, with the exception of naphthalene SOA, the intrinsic OP ${ }^{\mathrm{WS}-\mathrm{DTT}}$ does not appear to be affected by $\mathrm{N}: \mathrm{C}$ ratio even though the systems explored span a wide range of $\mathrm{N}: \mathrm{C}$. This is consistent with the results observed in the van Krevelen diagram and further emphasizes the importance of hydrocarbon identity in determining oxidative potentials.

\subsection{Comparison to other types of PM}

In order to evaluate how the oxidative potential of individual SOA systems compares to other sources and subtypes of $\mathrm{PM}$, the intrinsic OPWS-DTT values from this study are compared to values reported in the literature (Fig. 4). Comparatively, SOA formed from the photooxidation of isoprene, $\alpha$-pinene, $\beta$-caryophyllene, pentadecane, and $m$-xylene were not very DTT active and produced low intrinsic OPWS-DTT. The OPWS-DTT values of these aerosol systems were also within the range of various OA subtypes resolved from ambient data. The method for determining intrinsic OPWS-DTT for various OA subtypes is provided in the Supplement. As noted earlier, the OP ${ }^{\mathrm{WS}-\mathrm{DTT}}$ for isoprene SOA generated in this study is similar to the isoprene-derived OA factor from ambient data. The other ambient OA factors include a highly oxidized MO-OOA (more-oxidized oxygenated OA) factor resolved from PMF analysis of ambient OA data, as well as an oxidized organic aerosol factor containing contributions from biogenic SOA (other OC) resolved using the chemical mass balance (CMB) method with ensemble-averaged source impact profiles (Bates et al., 2015; Xu et al., 2015a, b; Verma et al., 2014). While sources of MO-OOA have not been identified, studies have shown that the aerosol mass spectra for various sources of OA approach those of MO-OOA as it ages ( $\mathrm{Ng}$ et al., 2010), and it has been speculated that MOOOA may contain aerosol from multiple aged sources (Xu et al., 2015b). Furthermore, MO-OOA has been shown to have widespread contributions across urban and rural sites, as well as different seasons (Xu et al., 2015a, b). Conversely, naphthalene SOA was highly DTT active with an OPWS-DTT on the order of biomass burning OA (BBOA (Verma et al., 2015a), BURN (Bates et al., 2015)). The BBOA and BURN factors were resolved using different source apportionment 
methods and as such, the range for comparison is large. Here, we focus on BBOA since Verma et al. (2015a) previously showed that BBOA had the highest intrinsic DTT activity among all OA subtypes resolved from PMF analysis of ambient AMS data collected in the southeastern US (see Fig. 4 for comparison). Because naphthalene aerosols formed under $\mathrm{RO}_{2}+\mathrm{NO}$-dominant conditions may be even more redox active than BBOA and anthropogenic emissions are more abundant in urban environments with higher $\mathrm{NO}_{x}$, this system warrants further systematic studies. It should however be noted that comparisons of intrinsic DTT activities between SOA from a pure VOC and an ambient source are difficult. BBOA is a source that contains many compounds, some of which may not be redox active. Thus, although it may contain highly DTT-active components with high intrinsic activities, the overall intrinsic activity will be much lower. As a result, a direct comparison with pure naphthalene SOA on a per mass basis is tenuous. However, naphthalene SOA formed under urban conditions $\left(\mathrm{RO}_{2}+\mathrm{NO}\right)$ also produces nitroaromatics, which may induce DNA breaks and other mutagenic effects (Baird et al., 2005; Helmig et al., 1992). As such, aerosols formed from photooxidation of PAHs may be a particularly important OA source in terms of PM health effects.

Other common sources of PM are those related to traffic. Previous studies have determined that products of incomplete combustion include quinones capable of participating in redox reactions, including the oxidation of DTT (Kumagai et al., 2002; McWhinney et al., 2013a). The SOA systems investigated, including isoprene, $\alpha$-pinene, $\beta$-caryophyllene, pentadecane, and $m$-xylene produced SOA that were less DTT active than diesel exhaust particles (DEPs) collected from light-duty diesel vehicle (LDDV) engines operated under various conditions (McWhinney et al., 2013a) and resolved for heavy-duty diesel vehicles (HDDVs) from ambient data (Bates et al., 2015). It should be noted that the DTT activity reported for DEPs includes both water-soluble and water-insoluble fractions (total DTT activity), whereas the DTT activity measured for SOA is water-soluble. However, there should be very little contribution from water-insoluble species to SOA (McWhinney et al., 2013a). Conversely, the intrinsic OPWS-DTT of naphthalene SOA was on par with that of light-duty gasoline vehicles (LDGVs) and higher than that of HDDVs and DEPs (Verma et al., 2014; Bates et al., 2015). Since naphthalene may also be emitted from gasoline and diesel combustion (Jia and Batterman, 2010), traffic-related controls may be extremely important to control these highly DTT-active sources. Furthermore, since SOA often dominate over POA (primary organic aerosols) even in urban centers (Zhang et al., 2007; $\mathrm{Ng}$ et al., 2011), even SOA that is only slightly DTT active may contribute significantly to PMinduced health effects.

\subsection{Implications}

The water-soluble oxidative potential, as measured by DTT consumption, was determined for SOA generated from six different hydrocarbon precursors under three conditions of varying humidity and $\mathrm{RO}_{2}$ fate. Results from this study demonstrate that hydrocarbon precursor identity influenced intrinsic SOA oxidative potential substantially. The biogenic and anthropogenic precursors investigated yielded SOA with OPWS-DTT values ranging from 9 to $205 \mathrm{pmol} \mathrm{min}^{-1} \mu \mathrm{g}^{-1}$, with isoprene SOA and naphthalene SOA having the lowest and highest intrinsic OPWS-DTT, respectively. In general, OP ${ }^{\text {WS-DTT }}$ values for biogenic SOA were lower than those for anthropogenic SOA. Therefore, to evaluate overall oxidative potentials of ambient SOA, hydrocarbon precursor emissions and their corresponding SOA formation potential must be considered. Moreover, it may be possible to roughly estimate regional oxidative potentials using individual intrinsic OP ${ }^{\text {WS-DTT }}$ of different types of SOA in conjunction with VOC emissions and SOA loadings in models. For instance, DTT activities of aerosols collected in Beijing, China (77-111 $\mathrm{pmol} \mathrm{min}^{-1} \mu \mathrm{g}^{-1}$; Lu et al., 2014), where anthropogenic emissions dominate, more closely resemble the OPWS-DTT of naphthalene SOA. Conversely, ambient aerosols collected in the southeastern US have DTT activities (25-36 $\mathrm{pmol} \mathrm{min}^{-1} \mathrm{\mu g}^{-1}$; Fang et al., 2015b) that more closely resemble those of biogenic SOA. It may therefore be informative to investigate whether concentration addition can be applied to DTT consumption by exploring wellcharacterized PM mixtures.

Chamber reaction conditions, including relative humidity and specific $\mathrm{RO}_{2}$ fate, influenced SOA elemental composition substantially and affected OPWS-DTT in a hydrocarbonspecific manner, although hydrocarbon identity was by far the most influential in determining OP ${ }^{\text {WS-DTT }}$. For several VOCs (isoprene, $\alpha$-pinene, $\beta$-caryophyllene, and pentadecane), the reaction conditions had a negligible effect on OP ${ }^{\text {WS-DTT }}$, which suggests that the organic peroxides and organic nitrates formed from the oxidation of these precursors may have similarly low redox activity. An investigation into the redox activity of individual known photooxidation products, including organic peroxides and organic nitrates, may elucidate further information on the lack of reaction condition effect. Similarly, nitroaromatics may explain the difference observed between naphthalene aerosol formed under different $\mathrm{RO}_{2}$ reaction pathways since the nitrite group may promote electron transfer and result in a higher OPWS-DTT. This effect was not observed for $m$-xylene SOA due to the formation of predominantly ring-opening products. The loss of the aromatic ring may also explain the differences in intrinsic OPWS-DTT. For instance, naphthalene SOA, which contains many aromatic ring-retaining products, is as redox active as BBOA, one of the most DTT-active aerosol subtypes found in ambient studies. Conversely, $m$-xylene SOA with predominantly aromatic ring-breaking products 
is much less redox active and the measured OPWS-DTT is lower than that of traffic-related sources and several OA subtypes (BBOA and cooking OA, COA). This further supports earlier findings (Verma et al., 2015b) that the polyaromatic ring structure may be an important consideration for understanding SOA redox activity, which may have implications for cellular redox imbalance (Tuet et al., 2016). Furthermore, nitroaromatics and polyaromatics may also have significant health effects beyond redox imbalance, including various mutagenic effects (Baird et al., 2005; Helmig et al., 1992). As such, hydrocarbon precursors forming aromatic ring-retaining products may be the most important to consider in PM-induced health effects in terms of oxidative potential. This is consistent with many studies using DTT to show oxidative potential associated with sources related to incomplete combustion (Bates et al., 2015; Verma et al., 2014; McWhinney et al., 2013b) and the identification of HULIS (Verma et al., 2015b; Dou et al., 2015; Lin and Yu, 2011), and more specifically, quinones as key components contributing to oxidative potential (Verma et al., 2014). Finally, redox-active metals are also emitted by traffic through mechanical processes, such as brake and tire wear (Charrier and Anastasio, 2012; Fang et al., 2015a). These species were not considered in the chamber experiments explored in this study. Inclusion of redox-active metals in future SOA experiments may be valuable to further understand the roles of SOA and metal species in overall redox activity.

\section{Abbreviations}

PM: particulate matter, SOA: secondary organic aerosol, ROS/RNS: reactive oxygen and nitrogen species, DTT: dithiothreitol, OPWS: oxidative potential of water-soluble species.

\section{Data availability}

Data are available upon request to the corresponding author (ng@ chbe.gatech.edu).

\section{The Supplement related to this article is available online at doi:10.5194/acp-17-839-2017-supplement.}

Acknowledgement. This work was supported by the Health Effects Institute under research agreement no. 4943-RFA13-2/14-4. Wing Y. Tuet acknowledges support by the National Science Foundation Graduate Research Fellowship under Grant no. DGE1148903 .

Edited by: A. S. H. Prévôt

Reviewed by: two anonymous referees

\section{References}

Anderson, J. O., Thundiyil, J. G., and Stolbach, A.: Clearing the Air: A Review of the Effects of Particulate Matter Air Pollution on Human Health, Journal of Medical Toxicology, 8, 166-175, doi:10.1007/s13181-011-0203-1, 2011.

Arashiro, M., Lin, Y.-H., Sexton, K. G., Zhang, Z., Jaspers, I., Fry, R. C., Vizuete, W. G., Gold, A., and Surratt, J. D.: In vitro exposure to isoprene-derived secondary organic aerosol by direct deposition and its effects on $C O X-2$ and $I L-8$ gene expression, Atmos. Chem. Phys., 16, 14079-14090, doi:10.5194/acp16-14079-2016, 2016.

Bahreini, R., Keywood, M. D., Ng, N. L., Varutbangkul, V., Gao, S., Flagan, R. C., Seinfeld, J. H., Worsnop, D. R., and Jimenez, J. L.: Measurements of Secondary Organic Aerosol from Oxidation of Cycloalkenes, Terpenes, and m-Xylene Using an Aerodyne Aerosol Mass Spectrometer, Environ. Sci. Technol., 39, 56745688, doi:10.1021/es048061a, 2005.

Bai, Y., Suzuki, A. K., and Sagai, M.: The cytotoxic effects of diesel exhaust particles on human pulmonary artery endothelial cells in vitro: role of active oxygen species, Free Radical Bio. Med., 30, 555-562, doi:10.1016/S0891-5849(00)00499-8, 2001.

Baird, W. M., Hooven, L. A., and Mahadevan, B.: Carcinogenic polycyclic aromatic hydrocarbon-DNA adducts and mechanism of action, Environ. Mol. Mutagen., 45, 106-114, doi:10.1002/em.20095, 2005.

Baltensperger, U., Dommen, J., Alfarra, R., Duplissy, J., Gaeggeler, K., Metzger, A., Facchini, M. C., Decesari, S., Finessi, E., Reinnig, C., Schott, M., Warnke, J., Hoffmann, T., Klatzer, B., Puxbaum, H., Geiser, M., Savi, M., Lang, D., Kalberer, M., and Geiser, T.: Combined determination of the chemical composition and of health effects of secondary organic aerosols: The POLYSOA project, J. Aerosol Med. Pulm. Drug Deliv., 21, 145154, doi:10.1089/jamp.2007.0655, 2008.

Bates, J. T., Weber, R. J., Abrams, J., Verma, V., Fang, T., Klein, M., Strickland, M. J., Sarnat, S. E., Chang, H. H., Mulholland, J. A., Tolbert, P. E., and Russell, A. G.: Reactive Oxygen Species Generation Linked to Sources of Atmospheric Particulate Matter and Cardiorespiratory Effects, Environ. Sci. Technol., 49, 13605-13612, doi:10.1021/acs.est.5b02967, 2015.

Boyd, C. M., Sanchez, J., Xu, L., Eugene, A. J., Nah, T., Tuet, W. Y., Guzman, M. I., and Ng, N. L.: Secondary organic aerosol formation from the $\beta$ pinene $+\mathrm{NO}_{3}$ system: effect of humidity and peroxy radical fate, Atmos. Chem. Phys., 15, 7497-7522, doi:10.5194/acp-15-7497-2015, 2015.

Brunekreef, B. and Holgate, S. T.: Air pollution and health, Lancet, 360, 1233-1242, 2002.

Bruns, E. A., Perraud, V., Zelenyuk, A., Ezell, M. J., Johnson, S. N., Yu, Y., Imre, D., Finlayson-Pitts, B. J., and Alexander, M. L.: Comparison of FTIR and Particle Mass Spectrometry for the Measurement of Particulate Organic Nitrates, Environ. Sci. Technol., 44, 1056-1061, doi:10.1021/es9029864, 2010.

Bruns, E. A., El Haddad, I., Slowik, J. G., Kilic, D., Klein, F., Baltensperger, U., and Prévôt, A. S. H.: Identification of significant precursor gases of secondary organic aerosols from residential wood combustion, Sci. Rep., 6, 27881, doi:10.1038/srep27881, 2016.

Canagaratna, M. R., Jimenez, J. L., Kroll, J. H., Chen, Q., Kessler, S. H., Massoli, P., Hildebrandt Ruiz, L., Fortner, E., Williams, L. R., Wilson, K. R., Surratt, J. D., Donahue, N. M., Jayne, J. T., 
and Worsnop, D. R.: Elemental ratio measurements of organic compounds using aerosol mass spectrometry: characterization, improved calibration, and implications, Atmos. Chem. Phys., 15, 253-272, doi:10.5194/acp-15-253-2015, 2015.

Castro, L. and Freeman, B. A.: Reactive oxygen species in human health and disease, Nutrition, 17, 161-165, 2001.

Chan, A. W. H., Kautzman, K. E., Chhabra, P. S., Surratt, J. D., Chan, M. N., Crounse, J. D., Kürten, A., Wennberg, P. O., Flagan, R. C., and Seinfeld, J. H.: Secondary organic aerosol formation from photooxidation of naphthalene and alkylnaphthalenes: implications for oxidation of intermediate volatility organic compounds (IVOCs), Atmos. Chem. Phys., 9, 3049-3060, doi:10.5194/acp-9-3049-2009, 2009.

Chan, A. W. H., Chan, M. N., Surratt, J. D., Chhabra, P. S., Loza, C. L., Crounse, J. D., Yee, L. D., Flagan, R. C., Wennberg, P. O., and Seinfeld, J. H.: Role of aldehyde chemistry and $\mathrm{NO}_{x}$ concentrations in secondary organic aerosol formation, Atmos. Chem. Phys., 10, 7169-7188, doi:10.5194/acp-10-7169-2010, 2010.

Charrier, J. G. and Anastasio, C.: On dithiothreitol (DTT) as a measure of oxidative potential for ambient particles: evidence for the importance of soluble transition metals, Atmos. Chem. Phys., 12, 9321-9333, doi:10.5194/acp-12-9321-2012, 2012.

Chhabra, P. S., Flagan, R. C., and Seinfeld, J. H.: Elemental analysis of chamber organic aerosol using an aerodyne high-resolution aerosol mass spectrometer, Atmos. Chem. Phys., 10, 4111-4131, doi:10.5194/acp-10-4111-2010, 2010.

Chhabra, P. S., Ng, N. L., Canagaratna, M. R., Corrigan, A. L., Russell, L. M., Worsnop, D. R., Flagan, R. C., and Seinfeld, J. H.: Elemental composition and oxidation of chamber organic aerosol, Atmos. Chem. Phys., 11, 8827-8845, doi:10.5194/acp-11-88272011, 2011.

Cho, A. K., Sioutas, C., Miguel, A. H., Kumagai, Y., Schmitz, D. A., Singh, M., Eiguren-Fernandez, A., and Froines, J. R.: Redox activity of airborne particulate matter at different sites in the Los Angeles Basin, Environ. Res., 99, 40-47, doi:10.1016/j.envres.2005.01.003, 2005.

Cocker III, D. R., Mader, B. T., Kalberer, M., Flagan, R. C., and Seinfeld, J. H.: The effect of water on gas-particle partitioning of secondary organic aerosol: II. m-xylene and 1,3,5trimethylbenzene photooxidation systems, Atmos. Environ., 35, 6073-6085, doi:10.1016/S1352-2310(01)00405-8, 2001.

Conny, J. M. and Slater, J. F.: Black carbon and organic carbon in aerosol particles from crown fires in the Canadian boreal forest, J. Geophys. Res.-Atmos., 107, AAC 4-1-AAC 4-12, doi:10.1029/2001JD001528, 2002.

DeCarlo, P. F., Kimmel, J. R., Trimborn, A., Northway, M. J., Jayne, J. T., Aiken, A. C., Gonin, M., Fuhrer, K., Horvath, T., Docherty, K. S., Worsnop, D. R., and Jimenez, J. L.: Field-Deployable, High-Resolution, Time-of-Flight Aerosol Mass Spectrometer, Anal. Chem., 78, 8281-8289, doi:10.1021/ac061249n, 2006.

Dockery, D. W., Pope, C. A., Xu, X., Spengler, J. D., Ware, J. H., Fay, M. E., Ferris, B. G., and Speizer, F. E.: An Association between Air Pollution and Mortality in Six U.S. Cities, New England Journal of Medicine, 329, 1753-1759, doi:10.1056/NEJM199312093292401, 1993.

Dou, J., Lin, P., Kuang, B.-Y., and Yu, J. Z.: Reactive Oxygen Species Production Mediated by Humic-like Substances in Atmospheric Aerosols: Enhancement Effects by Pyridine, Imida- zole, and Their Derivatives, Environ. Sci. Technol., 49, 64576465, doi:10.1021/es5059378, 2015.

Eddingsaas, N. C., Loza, C. L., Yee, L. D., Chan, M., Schilling, K. A., Chhabra, P. S., Seinfeld, J. H., and Wennberg, P. O.: $\alpha$-pinene photooxidation under controlled chemical conditions - Part 2: SOA yield and composition in low- and high- $\mathrm{NO}_{x}$ environments, Atmos. Chem. Phys., 12, 7413-7427, doi:10.5194/acp-12-74132012, 2012.

Edney, E. O., Driscoll, D. J., Speer, R. E., Weathers, W. S., Kleindienst, T. E., Li, W., and Smith, D. F.: Impact of aerosol liquid water on secondary organic aerosol yields of irradiated toluene/propylene/NOx/(NH4)2SO4/air mixtures, Atmos. Environ., 34, 3907-3919, doi:10.1016/S1352-2310(00)00174-6, 2000.

Fang, T., Guo, H., Verma, V., Peltier, R. E., and Weber, R. J.: $\mathrm{PM}_{2.5}$ water-soluble elements in the southeastern United States: automated analytical method development, spatiotemporal distributions, source apportionment, and implications for heath studies, Atmos. Chem. Phys., 15, 11667-11682, doi:10.5194/acp-1511667-2015, 2015a.

Fang, T., Verma, V., Guo, H., King, L. E., Edgerton, E. S., and Weber, R. J.: A semi-automated system for quantifying the oxidative potential of ambient particles in aqueous extracts using the dithiothreitol (DTT) assay: results from the Southeastern Center for Air Pollution and Epidemiology (SCAPE), Atmos. Meas. Tech., 8, 471-482, doi:10.5194/amt-8-471-2015, 2015b.

Fang, T., Verma, V., Bates, J. T., Abrams, J., Klein, M., Strickland, M. J., Sarnat, S. E., Chang, H. H., Mulholland, J. A., Tolbert, P. E., Russell, A. G., and Weber, R. J.: Oxidative potential of ambient water-soluble $\mathrm{PM}_{2.5}$ in the southeastern United States: contrasts in sources and health associations between ascorbic acid (AA) and dithiothreitol (DTT) assays, Atmos. Chem. Phys., 16, 3865-3879, doi:10.5194/acp-16-3865-2016, 2016.

Farmer, D. K., Matsunaga, A., Docherty, K. S., Surratt, J. D., Seinfeld, J. H., Ziemann, P. J., and Jimenez, J. L.: Response of an aerosol mass spectrometer to organonitrates and organosulfates and implications for atmospheric chemistry, P. Natl. Acad. Sci USA, 107, 6670-6675, doi:10.1073/pnas.0912340107, 2010.

Fry, J. L., Kiendler-Scharr, A., Rollins, A. W., Wooldridge, P. J., Brown, S. S., Fuchs, H., Dubé, W., Mensah, A., dal Maso, M., Tillmann, R., Dorn, H.-P., Brauers, T., and Cohen, R. C.: Organic nitrate and secondary organic aerosol yield from $\mathrm{NO}_{3}$ oxidation of $\beta$-pinene evaluated using a gas-phase kinetics/aerosol partitioning model, Atmos. Chem. Phys., 9, 14311449, doi:10.5194/acp-9-1431-2009, 2009.

Goldstein, A. H. and Galbally, I. E.: Known and Unexplored Organic Constituents in the Earth's Atmosphere, Environ. Sci. Technol., 41, 1514-1521, doi:10.1021/es072476p, 2007.

Guenther, A., Karl, T., Harley, P., Wiedinmyer, C., Palmer, P. I., and Geron, C.: Estimates of global terrestrial isoprene emissions using MEGAN (Model of Emissions of Gases and Aerosols from Nature), Atmos. Chem. Phys., 6, 3181-3210, doi:10.5194/acp-63181-2006, 2006.

Guenther, A. B., Zimmerman, P. R., Harley, P. C., Monson, R. K., and Fall, R.: Isoprene and monoterpene emission rate variability: Model evaluations and sensitivity analyses, J. Geophys. Res.Atmos., 98, 12609-12617, doi:10.1029/93JD00527, 1993.

Gurgueira, S. A., Lawrence, J., Coull, B., Murthy, G. G. K., and Gonzalez-Flecha, B.: Rapid increases in the steady-state concen- 
tration of reactive oxygen species in the lungs and heart after particulate air pollution inhalation, Environ. Health Persp., 110, 749-755, 2002.

Hamad, S. H., Shafer, M. M., Kadhim, A. K. H., Al-Omran, S. M., and Schauer, J. J.: Seasonal trends in the composition and ROS activity of fine particulate matter in Baghdad, Iraq, Atmos. Environ., 100, 102-110, doi:10.1016/j.atmosenv.2014.10.043, 2015.

Heald, C. L., Kroll, J. H., Jimenez, J. L., Docherty, K. S., DeCarlo, P. F., Aiken, A. C., Chen, Q., Martin, S. T., Farmer, D. K., and Artaxo, P.: A simplified description of the evolution of organic aerosol composition in the atmosphere, Geophys. Res. Lett., 37, L08803, doi:10.1029/2010GL042737, 2010.

Healy, R. M., Temime, B., Kuprovskyte, K., and Wenger, J. C.: Effect of Relative Humidity on Gas/Particle Partitioning and Aerosol Mass Yield in the Photooxidation of p-Xylene, Environ. Sci. Technol., 43, 1884-1889, doi:10.1021/es802404z, 2009.

Helmig, D., Arey, J., Harger, W. P., Atkinson, R., and LopezCancio, J.: Formation of mutagenic nitrodibenzopyranones and their occurrence in ambient air, Environ. Sci. Technol., 26, 622624, doi:10.1021/es00027a028, 1992.

Hensley, K., Robinson, K. A., Gabbita, S. P., Salsman, S., and Floyd, R. A.: Reactive oxygen species, cell signaling, and cell injury, Free Radical Bio. Med., 28, 1456-1462, doi:10.1016/S0891-5849(00)00252-5, 2000.

Hoek, G., Krishnan, R. M., Beelen, R., Peters, A., Ostro, B., Brunekreef, B., and Kaufman, J. D.: Long-term air pollution exposure and cardio-respiratory mortality: a review, Environ Health, 12, 43, doi:10.1186/1476-069x-12-43, 2013.

Hoffmann, T., Odum, J., Bowman, F., Collins, D., Klockow, D., Flagan, R., and Seinfeld, J.: Formation of Organic Aerosols from the Oxidation of Biogenic Hydrocarbons, J. Atmos. Chem., 26, 189222, doi:10.1023/A:1005734301837, 1997.

Janssen, N. A. H., Yang, A., Strak, M., Steenhof, M., Hellack, B., Gerlofs-Nijland, M. E., Kuhlbusch, T., Kelly, F., Harrison, R., Brunekreef, B., Hoek, G., and Cassee, F.: Oxidative potential of particulate matter collected at sites with different source characteristics, Sci. Total Environ., 472, 572-581, doi:10.1016/j.scitotenv.2013.11.099, 2014.

Jenkin, M. E., Saunders, S. M., Wagner, V., and Pilling, M. J.: Protocol for the development of the Master Chemical Mechanism, MCM v3 (Part B): tropospheric degradation of aromatic volatile organic compounds, Atmos. Chem. Phys., 3, 181-193, doi:10.5194/acp-3-181-2003, 2003.

Jia, C. and Batterman, S.: A Critical Review of Naphthalene Sources and Exposures Relevant to Indoor and Outdoor Air, International Journal of Environ. Res. Public Health, 7, 2903-2939, doi:10.3390/ijerph7072903, 2010.

Jimenez, J. L., Canagaratna, M. R., Donahue, N. M., Prevot, A. S. H., Zhang, Q., Kroll, J. H., DeCarlo, P. F., Allan, J. D., Coe, H., Ng, N. L., Aiken, A. C., Docherty, K. S., Ulbrich, I. M., Grieshop, A. P., Robinson, A. L., Duplissy, J., Smith, J. D., Wilson, K. R., Lanz, V. A., Hueglin, C., Sun, Y. L., Tian, J., Laaksonen, A., Raatikainen, T., Rautiainen, J., Vaattovaara, P., Ehn, M., Kulmala, M., Tomlinson, J. M., Collins, D. R., Cubison, M. J., Dunlea, J., Huffman, J. A., Onasch, T. B., Alfarra, M. R., Williams, P. I., Bower, K., Kondo, Y., Schneider, J., Drewnick, F., Borrmann, S., Weimer, S., Demerjian, K., Salcedo, D., Cottrell, L., Griffin, R., Takami, A., Miyoshi, T., Hatakeyama, S., Shimono, A., Sun, J. Y., Zhang, Y. M., Dzepina, K., Kimmel,
J. R., Sueper, D., Jayne, J. T., Herndon, S. C., Trimborn, A. M., Williams, L. R., Wood, E. C., Middlebrook, A. M., Kolb, C. E., Baltensperger, U., and Worsnop, D. R.: Evolution of Organic Aerosols in the Atmosphere, Science, 326, 1525-1529, doi:10.1126/science.1180353, 2009.

Kautzman, K. E., Surratt, J. D., Chan, M. N., Chan, A. W. H., Hersey, S. P., Chhabra, P. S., Dalleska, N. F., Wennberg, P. O., Flagan, R. C., and Seinfeld, J. H.: Chemical Composition of Gas- and Aerosol-Phase Products from the Photooxidation of Naphthalene, J. Phys. Chem. A, 114, 913-934, doi:10.1021/jp908530s, 2010.

Kleinman, M. T., Hamade, A., Meacher, D., Oldham, M., Sioutas, C., Chakrabarti, B., Stram, D., Froines, J. R., and Cho, A. K.: Inhalation of concentrated ambient particulate matter near a heavily trafficked road stimulates antigen-induced airway responses in mice, J. Air Waste Manage. Assoc., 55, 1277-1288, 2005.

Kramer, A. J., Rattanavaraha, W., Zhang, Z., Gold, A., Surratt, J. D., and Lin, Y.-H.: Assessing the oxidative potential of isoprenederived epoxides and secondary organic aerosol, Atmos. Environ., 130, 211-218, doi:10.1016/j.atmosenv.2015.10.018, 2016.

Kroll, J. H., Ng, N. L., Murphy, S. M., Flagan, R. C., and Seinfeld, J. H.: Secondary organic aerosol formation from isoprene photooxidation under high- $\mathrm{NO}_{x}$ conditions, Geophys. Res. Lett., 32, L18808, doi:10.1029/2005GL023637, 2005.

Kroll, J. H. and Seinfeld, J. H.: Chemistry of secondary organic aerosol: Formation and evolution of low-volatility organics in the atmosphere, Atmos. Environ., 42, 3593-3624, doi:10.1016/j.atmosenv.2008.01.003, 2008.

Kroll, J. H., Donahue, N. M., Jimenez, J. L., Kessler, S. H., Canagaratna, M. R., Wilson, K. R., Altieri, K. E., Mazzoleni, L. R., Wozniak, A. S., Bluhm, H., Mysak, E. R., Smith, J. D., Kolb, C. E., and Worsnop, D. R.: Carbon oxidation state as a metric for describing the chemistry of atmospheric organic aerosol, Nat. Chem., 3, 133-139, 2011.

Kumagai, Y., Koide, S., Taguchi, K., Endo, A., Nakai, Y., Yoshikawa, T., and Shimojo, N.: Oxidation of proximal protein sulfhydryls by phenanthraquinone, a component of diesel exhaust particles, Chem. Res. Toxicol., 15, 483-489, doi:10.1021/tx0100993, 2002.

Lambe, A. T., Onasch, T. B., Massoli, P., Croasdale, D. R., Wright, J. P., Ahern, A. T., Williams, L. R., Worsnop, D. R., Brune, W. H., and Davidovits, P.: Laboratory studies of the chemical composition and cloud condensation nuclei $(\mathrm{CCN})$ activity of secondary organic aerosol (SOA) and oxidized primary organic aerosol (OPOA), Atmos. Chem. Phys., 11, 8913-8928, doi:10.5194/acp11-8913-2011, 2011.

Li, N., Hao, M. Q., Phalen, R. F., Hinds, W. C., and Nel, A. E.: Particulate air pollutants and asthma - A paradigm for the role of oxidative stress in PM-induced adverse health effects, $\mathrm{Cl}$. Immunol., 109, 250-265, doi:10.1016/j.clim.2003.08.006, 2003a.

Li, N., Sioutas, C., Cho, A., Schmitz, D., Misra, C., Sempf, J., Wang, M. Y., Oberley, T., Froines, J., and Nel, A.: Ultrafine particulate pollutants induce oxidative stress and mitochondrial damage, Environ. Health Persp., 111, 455-460, doi:10.1289/ehp.6000, 2003b.

Li, N., Xia, T., and Nel, A. E.: The role of oxidative stress in ambient particulate matter-induced lung diseases and its implications in the toxicity of engineered nanoparticles, Free Radical Bio. Med., 
44, 1689-1699, doi:10.1016/j.freeradbiomed.2008.01.028, 2008.

Lim, S. S., Vos, T., Flaxman, A. D., Danaei, G., Shibuya, K., AdairRohani, H., AlMazroa, M. A., Amann, M., Anderson, H. R., Andrews, K. G., Aryee, M., Atkinson, C., Bacchus, L. J., Bahalim, A. N., Balakrishnan, K., Balmes, J., Barker-Collo, S., Baxter, A., Bell, M. L., Blore, J. D., Blyth, F., Bonner, C., Borges, G., Bourne, R., Boussinesq, M., Brauer, M., Brooks, P., Bruce, N. G., Brunekreef, B., Bryan-Hancock, C., Bucello, C., Buchbinder, R., Bull, F., Burnett, R. T., Byers, T. E., Calabria, B., Carapetis, J., Carnahan, E., Chafe, Z., Charlson, F., Chen, H., Chen, J. S., Cheng, A. T.-A., Child, J. C., Cohen, A., Colson, K. E., Cowie, B. C., Darby, S., Darling, S., Davis, A., Degenhardt, L., Dentener, F., Des Jarlais, D. C., Devries, K., Dherani, M., Ding, E. L., Dorsey, E. R., Driscoll, T., Edmond, K., Ali, S. E., Engell, R. E., Erwin, P. J., Fahimi, S., Falder, G., Farzadfar, F., Ferrari, A., Finucane, M. M., Flaxman, S., Fowkes, F. G. R., Freedman, G., Freeman, M. K., Gakidou, E., Ghosh, S., Giovannucci, E., Gmel, G., Graham, K., Grainger, R., Grant, B., Gunnell, D., Gutierrez, H. R., Hall, W., Hoek, H. W., Hogan, A., Hosgood III, H. D., Hoy, D., Hu, H., Hubbell, B. J., Hutchings, S. J., Ibeanusi, S. E., Jacklyn, G. L., Jasrasaria, R., Jonas, J. B., Kan, H., Kanis, J. A., Kassebaum, N., Kawakami, N., Khang, Y.-H., Khatibzadeh, S., Khoo, J.-P., Kok, C., Laden, F., Lalloo, R., Lan, Q., Lathlean, T., Leasher, J. L., Leigh, J., Li, Y., Lin, J. K., Lipshultz, S. E., London, S., Lozano, R., Lu, Y., Mak, J., Malekzadeh, R., Mallinger, L., Marcenes, W., March, L., Marks, R., Martin, R., McGale, P., McGrath, J., Mehta, S., Memish, Z. A., Mensah, G. A., Merriman, T. R., Micha, R., Michaud, C., Mishra, V., Hanafiah, K. M., Mokdad, A. A., Morawska, L., Mozaffarian, D., Murphy, T., Naghavi, M., Neal, B., Nelson, P. K., Nolla, J. M., Norman, R., Olives, C., Omer, S. B., Orchard, J., Osborne, R., Ostro, B., Page, A., Pandey, K. D., Parry, C. D. H., Passmore, E., Patra, J., Pearce, N., Pelizzari, P. M., Petzold, M., Phillips, M. R., Pope, D., Pope III, C. A., Powles, J., Rao, M., Razavi, H., Rehfuess, E. A., Rehm, J. T., Ritz, B., Rivara, F. P., Roberts, T., Robinson, C., Rodriguez-Portales, J. A., Romieu, I., Room, R., Rosenfeld, L. C., Roy, A., Rushton, L., Salomon, J. A., Sampson, U., SanchezRiera, L., Sanman, E., Sapkota, A., Seedat, S., Shi, P., Shield, K., Shivakoti, R., Singh, G. M., Sleet, D. A., Smith, E., Smith, K. R., Stapelberg, N. J. C., Steenland, K., Stöckl, H., Stovner, L. J., Straif, K., Straney, L., Thurston, G. D., Tran, J. H., Van Dingenen, R., van Donkelaar, A., Veerman, J. L., Vijayakumar, L., Weintraub, R., Weissman, M. M., White, R. A., Whiteford, H., Wiersma, S. T., Wilkinson, J. D., Williams, H. C., Williams, W., Wilson, N., Woolf, A. D., Yip, P., Zielinski, J. M., Lopez, A. D., Murray, C. J. L., and Ezzati, M.: A comparative risk assessment of burden of disease and injury attributable to 67 risk factors and risk factor clusters in 21 regions, 1990-2010: a systematic analysis for the Global Burden of Disease Study 2010, Lancet, 380, 2224-2260, doi:10.1016/S0140-6736(12)61766-8, 2012.

Lin, P. and Yu, J. Z.: Generation of Reactive Oxygen Species Mediated by Humic-like Substances in Atmospheric Aerosols, Environ. Sci. Technol., 45, 10362-10368, doi:10.1021/es2028229, 2011.

Lin, Y.-H., Zhang, Z., Docherty, K. S., Zhang, H., Budisulistiorini, S. H., Rubitschun, C. L., Shaw, S. L., Knipping, E. M., Edgerton, E. S., Kleindienst, T. E., Gold, A., and Surratt, J. D.: Isoprene Epoxydiols as Precursors to Secondary Organic
Aerosol Formation: Acid-Catalyzed Reactive Uptake Studies with Authentic Compounds, Environ. Sci. Technol., 46, 250258, doi:10.1021/es202554c, 2012.

Loza, C. L., Craven, J. S., Yee, L. D., Coggon, M. M., Schwantes, R. H., Shiraiwa, M., Zhang, X., Schilling, K. A., Ng, N. L., Canagaratna, M. R., Ziemann, P. J., Flagan, R. C., and Seinfeld, J. H.: Secondary organic aerosol yields of 12-carbon alkanes, Atmos. Chem. Phys., 14, 1423-1439, doi:10.5194/acp-14-14232014, 2014.

Lu, Y., Su, S., Jin, W., Wang, B., Li, N., Shen, H., Li, W., Huang, Y., Chen, H., Zhang, Y., Chen, Y., Lin, N., Wang, X., and Tao, S.: Characteristics and cellular effects of ambient particulate matter from Beijing, Environ. Pollut., 191, 63-69, doi:10.1016/j.envpol.2014.04.008, 2014.

Lund, A. K., Doyle-Eisele, M., Lin, Y. H., Arashiro, M., Surratt, J. D., Holmes, T., Schilling, K. A., Seinfeld, J. H., Rohr, A. C., Knipping, E. M., and McDonald, J. D.: The effects of alpha-pinene versus toluene-derived secondary organic aerosol exposure on the expression of markers associated with vascular disease, Inhal. Toxicol., 25, 309-324, doi:10.3109/08958378.2013.782080, 2013.

McDonald, J. D., Doyle-Eisele, M., Campen, M. J., Seagrave, J., Holmes, T., Lund, A., Surratt, J. D., Seinfeld, J. H., Rohr, A. C., and Knipping, E. M.: Cardiopulmonary response to inhalation of biogenic secondary organic aerosol, Inhal. Toxicol., 22, 253265, doi:10.3109/08958370903148114, 2010.

McDonald, J. D., Doyle-Eisele, M., Kracko, D., Lund, A., Surratt, J. D., Hersey, S. P., Seinfeld, J. H., Rohr, A. C., and Knipping, E. M.: Cardiopulmonary response to inhalation of secondary organic aerosol derived from gas-phase oxidation of toluene, Inhal. Toxicol., 24, 689-697, doi:10.3109/08958378.2012.712164, 2012.

McLafferty, F. W. and Tureček, F.: Interpretation of mass spectra, University science books, 1993.

McWhinney, R. D., Badali, K., Liggio, J., Li, S.-M., and Abbatt, J. P. D.: Filterable Redox Cycling Activity: A Comparison between Diesel Exhaust Particles and Secondary Organic Aerosol Constituents, Environ. Sci. Technol., 47, 3362-3369, doi:10.1021/es304676x, 2013a.

McWhinney, R. D., Zhou, S., and Abbatt, J. P. D.: Naphthalene SOA: redox activity and naphthoquinone gas-particle partitioning, Atmos. Chem. Phys., 13, 9731-9744, doi:10.5194/acp-139731-2013, 2013b.

Nah, T., McVay, R. C., Pierce, J. R., Seinfeld, J. H., and Ng, N. L.: Constraining uncertainties in particle wall-deposition correction during SOA formation in chamber experiments, Atmos. Chem. Phys. Discuss., doi:10.5194/acp-2016-820, in review, 2016.

Ng, N. L., Kroll, J. H., Keywood, M. D., Bahreini, R., Varutbangkul, V., Flagan, R. C., Seinfeld, J. H., Lee, A., and Goldstein, A. H.: Contribution of First- versus Second-Generation Products to Secondary Organic Aerosols Formed in the Oxidation of Biogenic Hydrocarbons, Environ. Sci. Technol., 40, 2283-2297, doi:10.1021/es052269u, 2006.

Ng, N. L., Chhabra, P. S., Chan, A. W. H., Surratt, J. D., Kroll, J. H., Kwan, A. J., McCabe, D. C., Wennberg, P. O., Sorooshian, A., Murphy, S. M., Dalleska, N. F., Flagan, R. C., and Seinfeld, J. H.: Effect of $\mathrm{NO}_{x}$ level on secondary organic aerosol (SOA) formation from the photooxidation of terpenes, Atmos. Chem. Phys., 7, 5159-5174, doi:10.5194/acp-7-5159-2007, 2007a. 
Ng, N. L., Kroll, J. H., Chan, A. W. H., Chhabra, P. S., Flagan, R. C., and Seinfeld, J. H.: Secondary organic aerosol formation from $m$-xylene, toluene, and benzene, Atmos. Chem. Phys., 7, 3909-3922, doi:10.5194/acp-7-3909-2007, 2007 b.

Ng, N. L., Canagaratna, M. R., Zhang, Q., Jimenez, J. L., Tian, J., Ulbrich, I. M., Kroll, J. H., Docherty, K. S., Chhabra, P. S., Bahreini, R., Murphy, S. M., Seinfeld, J. H., Hildebrandt, L., Donahue, N. M., DeCarlo, P. F., Lanz, V. A., Prévôt, A. S. H., Dinar, E., Rudich, Y., and Worsnop, D. R.: Organic aerosol components observed in Northern Hemispheric datasets from Aerosol Mass Spectrometry, Atmos. Chem. Phys., 10, 46254641, doi:10.5194/acp-10-4625-2010, 2010.

Ng, N. L., Canagaratna, M. R., Jimenez, J. L., Chhabra, P. S., Seinfeld, J. H., and Worsnop, D. R.: Changes in organic aerosol composition with aging inferred from aerosol mass spectra, Atmos. Chem. Phys., 11, 6465-6474, doi:10.5194/acp-11-64652011, 2011.

Nguyen, T. B., Roach, P. J., Laskin, J., Laskin, A., and Nizkorodov, S. A.: Effect of humidity on the composition of isoprene photooxidation secondary organic aerosol, Atmos. Chem. Phys., 11, 6931-6944, doi:10.5194/acp-11-6931-2011, 2011.

Philip, M., Rowley, D. A., and Schreiber, H.: Inflammation as a tumor promoter in cancer induction, Seminars in Cancer Biology, 14, 433-439, doi:10.1016/j.semcancer.2004.06.006, 2004.

Piccot, S. D., Watson, J. J., and Jones, J. W.: A global inventory of volatile organic compound emissions from anthropogenic sources, J. Geophys. Res.-Atmos., 97, 9897-9912, doi:10.1029/92JD00682, 1992.

Platt, S. M., Haddad, I. E., Pieber, S. M., Huang, R. J., Zardini, A. A., Clairotte, M., Suarez-Bertoa, R., Barmet, P., Pfaffenberger, L., Wolf, R., Slowik, J. G., Fuller, S. J., Kalberer, M., Chirico, R., Dommen, J., Astorga, C., Zimmermann, R., Marchand, N., Hellebust, S., Temime-Roussel, B., Baltensperger, U., and Prévôt, A. S. H.: Two-stroke scooters are a dominant source of air pollution in many cities, Nat. Commun., 5, 3749, doi:10.1038/ncomms4749, 2014.

Pope, C. A., Burnett, R. T., Thun, M. J., Calle, E. E., Krewski, D., Ito, K., and Thurston, G. D.: Lung cancer, cardiopulmonary mortality, and long-term exposure to fine particulate air pollution, Jama-J. Am. Med. Assoc., 287, 1132-1141, doi:10.1001/jama.287.9.1132, 2002.

Pope III, C. A. and Dockery, D. W.: Health effects of fine particulate air pollution: Lines that connect, J. Air Waste Manage. Assoc., 56, 709-742, 2006.

Rattanavaraha, W., Rosen, E., Zhang, H., Li, Q., Pantong, K., and Kamens, R. M.: The reactive oxidant potential of different types of aged atmospheric particles: An outdoor chamber study, Atmos. Environ., 45, 3848-3855, doi:10.1016/j.atmosenv.2011.04.002, 2011.

Riva, M., Robinson, E. S., Perraudin, E., Donahue, N. M., and Villenave, E.: Photochemical Aging of Secondary Organic Aerosols Generated from the Photooxidation of Polycyclic Aromatic Hydrocarbons in the Gas-Phase, Environ. Sci. Technol., 49, 54075416, doi:10.1021/acs.est.5b00442, 2015.

Robinson, A. L., Donahue, N. M., Shrivastava, M. K., Weitkamp, E. A., Sage, A. M., Grieshop, A. P., Lane, T. E., Pierce, J. R., and Pandis, S. N.: Rethinking Organic Aerosols: Semivolatile Emissions and Photochemical Aging, Science, 315, 1259-1262, doi:10.1126/science.1133061, 2007.
Sannigrahi, P., Sullivan, A. P., Weber, R. J., and Ingall, E. D.: Characterization of Water-Soluble Organic Carbon in Urban Atmospheric Aerosols Using Solid-State 13C NMR Spectroscopy, Environ. Sci. Technol., 40, 666-672, doi:10.1021/es051150i, 2006.

Sato, K., Takami, A., Isozaki, T., Hikida, T., Shimono, A., and Imamura, T.: Mass spectrometric study of secondary organic aerosol formed from the photo-oxidation of aromatic hydrocarbons, Atmos. Environ., 44, 1080-1087, doi:10.1016/j.atmosenv.2009.12.013, 2010.

Stirnweis, L., Marcolli, C., Dommen, J., Barmet, P., Frege, C., Platt, S. M., Bruns, E. A., Krapf, M., Slowik, J. G., Wolf, R., Prévôt, A. S. H., El-Haddad, I., and Baltensperger, U.: $\alpha$-Pinene secondary organic aerosol yields increase at higher relative humidity and low $\mathrm{NO}_{x}$ conditions, Atmos. Chem. Phys. Discuss., doi:10.5194/acp-2016-717, in review, 2016.

Surratt, J. D., Chan, A. W. H., Eddingsaas, N. C., Chan, M., Loza, C. L., Kwan, A. J., Hersey, S. P., Flagan, R. C., Wennberg, P. O., and Seinfeld, J. H.: Reactive intermediates revealed in secondary organic aerosol formation from isoprene, P. Natl. Acad. Sci. USA, 107, 6640-6645, doi:10.1073/pnas.0911114107, 2010.

Tao, F., Gonzalez-Flecha, B., and Kobzik, L.: Reactive oxygen species in pulmonary inflammation by ambient particulates, Free Radical Bio. Med., 35, 327-340, doi:10.1016/S08915849(03)00280-6, 2003.

Tasoglou, A. and Pandis, S. N.: Formation and chemical aging of secondary organic aerosol during the $\beta$-caryophyllene oxidation, Atmos. Chem. Phys., 15, 6035-6046, doi:10.5194/acp-15-60352015, 2015.

Tuet, W. Y., Fok, S., Verma, V., Tagle Rodriguez, M. S., Grosberg, A., Champion, J. A., and Ng, N. L.: Dose-dependent intracellular reactive oxygen and nitrogen species production from particulate matter exposure: comparison to oxidative potential and chemical composition, Atmos. Environ., 144, 335-344, doi:10.1016/j.atmosenv.2016.09.005, 2016.

Turner, J., Hernandez, M., Snawder, J. E., Handorean, A., and McCabe, K. M.: A Toxicology Suite Adapted for Comparing Parallel Toxicity Responses of Model Human Lung Cells to Diesel Exhaust Particles and Their Extracts, Aerosol Sci. Technol., 49, 599-610, doi:10.1080/02786826.2015.1053559, 2015.

Van Krevelen, D.: Graphical-statistical method for the study of structure and reaction processes of coal, Fuel, 29, 269-284, 1950.

Verma, V., Rico-Martinez, R., Kotra, N., King, L., Liu, J. M., Snell, T. W., and Weber, R. J.: Contribution of Water-Soluble and Insoluble Components and Their Hydrophobic/Hydrophilic Subfractions to the Reactive Oxygen Species-Generating Potential of Fine Ambient Aerosols, Environ. Sci. Technol., 46, 11384 11392, doi:10.1021/es302484r, 2012.

Verma, V., Fang, T., Guo, H., King, L., Bates, J. T., Peltier, R. E., Edgerton, E., Russell, A. G., and Weber, R. J.: Reactive oxygen species associated with water-soluble $\mathrm{PM}_{2.5}$ in the southeastern United States: spatiotemporal trends and source apportionment, Atmos. Chem. Phys., 14, 12915-12930, doi:10.5194/acp14-12915-2014, 2014.

Verma, V., Fang, T., Xu, L., Peltier, R. E., Russell, A. G., Ng, N. L., and Weber, R. J.: Organic Aerosols Associated with the Generation of Reactive Oxygen Species (ROS) by Water-Soluble PM2.5, Environ. Sci. Technol., 49, 4646-4656, doi:10.1021/es505577w, 2015a. 
Verma, V., Wang, Y., El-Afifi, R., Fang, T., Rowland, J., Russell, A. G., and Weber, R. J.: Fractionating ambient humic-like substances (HULIS) for their reactive oxygen species activity - Assessing the importance of quinones and atmospheric aging, Atmos. Environ., 120, 351-359, doi:10.1016/j.atmosenv.2015.09.010, 2015b.

Visentin, M., Pagnoni, A., Sarti, E., and Pietrogrande, M. C.: Urban PM2.5 oxidative potential: Importance of chemical species and comparison of two spectrophotometric cell-free assays, Environ. Pollut., 219, 72-79, doi:10.1016/j.envpol.2016.09.047, 2016.

Vivanco, M. G. and Santiago, M.: Secondary Organic Aerosol Formation from the Oxidation of a Mixture of Organic Gases in a Chamber, Air Quality, edited by: Kumar, A., InTech, doi:10.5772/9761, 2010.

Weichenthal, S. A., Lavigne, E., Evans, G. J., Godri Pollitt, K. J., and Burnett, R. T.: Fine Particulate Matter and Emergency Room Visits for Respiratory Illness. Effect Modification by Oxidative Potential, Am. J. Resp. Crit. Care, 194, 577-586, doi:10.1164/rccm.201512-2434OC, 2016.

Wennberg, P.: Let's abandon the "high $\mathrm{NO}_{x}$ " and "low $\mathrm{NO}_{x}$ " terminology, IGAC news, 50, 3-4, 2013.

Wiseman, H. and Halliwell, B.: Damage to DNA by reactive oxygen and nitrogen species: role in inflammatory disease and progression to cancer, Biochem. J., 313, 17-29, 1996.

Wong, J. P. S., Lee, A. K. Y., and Abbatt, J. P. D.: Impacts of Sulfate Seed Acidity and Water Content on Isoprene Secondary Organic Aerosol Formation, Environ. Sci. Technol., 49, 13215-13221, doi:10.1021/acs.est.5b02686, 2015.

Xu, L., Kollman, M. S., Song, C., Shilling, J. E., and Ng, N. L.: Effects of NOx on the Volatility of Secondary Organic Aerosol from Isoprene Photooxidation, Environ. Sci. Technol., 48, 2253 2262, doi:10.1021/es404842g, 2014.
Xu, L., Guo, H., Boyd, C. M., Klein, M., Bougiatioti, A., Cerully, K. M., Hite, J. R., Isaacman-VanWertz, G., Kreisberg, N. M., Knote, C., Olson, K., Koss, A., Goldstein, A. H., Hering, S. V., de Gouw, J., Baumann, K., Lee, S.-H., Nenes, A., Weber, R. J., and Ng, N. L.: Effects of anthropogenic emissions on aerosol formation from isoprene and monoterpenes in the southeastern United States, P. Natl. Acad. Sci. USA, 112, 37-42, doi:10.1073/pnas.1417609112, 2015a.

Xu, L., Suresh, S., Guo, H., Weber, R. J., and Ng, N. L.: Aerosol characterization over the southeastern United States using highresolution aerosol mass spectrometry: spatial and seasonal variation of aerosol composition and sources with a focus on organic nitrates, Atmos. Chem. Phys., 15, 7307-7336, doi:10.5194/acp15-7307-2015, 2015b.

Yang, A., Janssen, N. A. H., Brunekreef, B., Cassee, F. R., Hoek, G., and Gehring, U.: Children's respiratory health and oxidative potential of PM2.5: the PIAMA birth cohort study, Occupational and Environmental Medicine, doi:10.1136/oemed-2015-103175, 2016.

Zhang, Q., Jimenez, J. L., Canagaratna, M. R., Allan, J. D., Coe, H., Ulbrich, I., Alfarra, M. R., Takami, A., Middlebrook, A. M., Sun, Y. L., Dzepina, K., Dunlea, E., Docherty, K., DeCarlo, P. F., Salcedo, D., Onasch, T., Jayne, J. T., Miyoshi, T., Shimono, A., Hatakeyama, S., Takegawa, N., Kondo, Y., Schneider, J., Drewnick, F., Borrmann, S., Weimer, S., Demerjian, K., Williams, P., Bower, K., Bahreini, R., Cottrell, L., Griffin, R. J., Rautiainen, J., Sun, J. Y., Zhang, Y. M., and Worsnop, D. R.: Ubiquity and dominance of oxygenated species in organic aerosols in anthropogenically-influenced Northern Hemisphere midlatitudes, Geophys. Res. Lett., 34, L13801, doi:10.1029/2007GL029979, 2007. 